\title{
Assessing Barriers to Trade in Services in India: An Empirical Investigation
}

\author{
Prabir De
}

Research and Information System for Developing Countries(RIS), New Delhi, India

\begin{abstract}
International trade in services has become more important in recent years as advances in technology have permitted new means of providing services across borders. Services have emerged as crucial economic activities in India, more prominently over the last decade. Apart from providing the bulk of employment and income in India, the services sector also serves as a vital input for producing other goods and services. While a large part of India's services sector is untapped and rarely explored by the international market, a growing number of barriers have been impeding India's international market access in the services sector. In this article, we performed a gravity analysis of the linkages between India's services trade flow and its probable barriers. The estimated results show that a 1 per cent improvement in services trade facilitation measures would lead to a 2 per cent rise in services exports in India. The paper concludes that improved trade facilitation may help unlock unrealized services trade potential, and, therefore, more effective policy toward an improved services trade infrastructure would be needed to facilitate services exports from India.
\end{abstract}

JEL Classifications: F13, F18

Key Words: India, Services Trade, Trade Facilitation, Services Trade Facilitation Index, Domestic Regulations, Gravity Model

\footnotetext{
* Corresponding Author: Prabir De; Research and Information System for Developing Countries (RIS), India Habitat Centre, Lodhi Road, New Delhi 110003, India, Tel: +91 11 24682177, Fax: +91 11 24682174, E-mail: prabirde@ hotmail.com 


\section{Introduction}

International trade in services has become more important in recent years as advances in technology have permitted new means of providing services across borders. While there is little doubt that services trade is an essential ingredient to economic growth, it is widely accepted that it can only make positive contributions if appropriately liberalized and implemented across countries (Copeland and Mattoo, 2008). An efficient services sector is crucial for the growth and competitiveness of individual firms as well as an economy. Francois and Hoekman (2010) commented in a seminal paper:

\footnotetext{
"There is increasing evidence that services liberalization is a major potential source of gains in economic performance, including productivity in manufacturing and the coordination of activities both between and within firms. The performance of service sectors, and thus services policies, may also be an important determinant of trade volumes, the distributional effects of trade, overall patterns of economic growth and development." (p. 642)
}

During the last two decades, India has turned from a rather closed economy into a nation strongly integrated into the world economy. The ratio of trade to India's GDP consistently rose over a 20-year period, from 15 per cent in 1990 to 55 per cent in 2010. 'While in relation to goods, India has turned from an importer of commodities in 1990s to a net exporter of intermediate goods in the late 2000s, in relation to services, India has continued to retain her prime position as the world's largest exporter of information technology services. In important sectors, inward FDI (Foreign Direct Investment) has played a key role, both in the expansion of trade and the transfer of technology. In this changing period, services have emerged as crucial economic activities for developing countries like India. Not only providing the bulk of employment and income in India, the services sector also serves as a vital input for the production of other goods and services. The importance of services is, therefore, increasingly reflected in the global trade policy agenda - ranging from liberalization and promotional efforts to regulation at the national and international levels. ${ }^{2}$ While a large part of India's services sector is untapped and rarely explored by the international market, a growing number of barriers have been impeding India's international market access in the services sector.

One precondition of the trade-led growth process is that trade liberalization has to be actively supported by trade facilitation in order to maximize the welfare gain. ${ }^{4}$ Falling short

\footnotetext{
${ }^{1}$ Here, trade counts both trade in goods and services; data was sourced from the World Development Indicators Online Database, The World Bank, Washington, D.C.

${ }^{2}$ For an excellent literature review, see Francois and Hoekman (2010).

${ }^{3}$ Refer, for example, to Chanda (2006).

${ }^{4}$ Refer, for example, to Bhagwati (1987).
} 
of adequate trade facilitation would lead to suboptimal trade, or, in other words, the trade potential would remain unexploited. Removal of these barriers through liberalization, and complementary regulatory reforms can lead to both sectoral and economy-wide improvements in performance and generate pro-poor growth. Since a large part of India's GDP is services driven, it is, therefore, important for us to assess the barriers to India's services exports, as this information is needed at different stages of the trade policy-making process in India.

In view of the above, the objective of this study is to assess the barriers to trade in services in India. We attempt to achieve this objective through an augmented gravity model, which relates the level of trade between countries to their physical and economic characteristics. The rest part of the paper is arranged as follows. Section II presents an overview of India's services trade sector. A brief discussion on literature is then provided in Section III. Section IV presents data and methodology. Measuring services trade facilitation is discussed in Section V. The determinants of India's services exports and barriers, based on augmented three-stage gravity model estimates, are then discussed in Section VI. Finally, conclusions are provided in Section VII.

\section{Services Trade in India: An Overview}

India has witnessed a gradual structural shift towards the services sector in the past decades, with services comprising a growing share of GDP and employment. Today, the services sector in India represents an essential component of the competitive, knowledge-based economy, accounting for 57.2 per cent of GDP.

Trade in services in India has been growing rapidly since the beginning of the last decade, following significant domestic liberalization and access to a growing overseas market for services. India's services exports currently constitutes about 38 per cent of the country's total exports. Services exports not only grew more rapidly than the country's merchandise exports, but also increased at a much faster rate than the world average during the past decade and a half. Due to such rapid growth in services exports, India has succeeded in raising its penetration in global markets more rapidly for services than for goods. For example, India's exports of services in 2010 stood at over US\$ 225 billion (Table 1), of which the value of exports and imports were US\$ 116 billion and US\$ 109 billion, respectively. In 2010, India's share in world services trade was around 3 per cent, increasing from slightly above the 1 per cent witnessed at the beginning of the last decade. Therefore, the expansion of services trade in India in the last decade was phenomenal; both exports and imports in services increased much more quickly than that of world exports and imports (Table 1). Today, services trade contributes over 12 per cent of India's GDP. It increased from a mere 3 per cent when India embraced the globalization

\footnotetext{
${ }^{5}$ Refer to Government of India (2010), Chapter 1, p. 5. Data relates to the years 2009 2010.
} 
process at the beginning of the 1990s (Table 2). Faster export growth over imports in services has also led to a growing surplus in the trade balance, except for the year 1995 1996 (Table 2).

Services exports from India have grown faster than imports in the last decade, thus widening the positive balance of trade. For example, computer and information technology services, which increased from US\$ 4.73 billion in 2000 to US\$ 56.70 billion in 2010, grew at a compound annual growth rate (CAGR) of 25.34 per cent between 2000 and 2010 (Table $3)$. Today, this sector alone contributes to almost half of India's total services exports, which a decade ago contributed about $1 / 4$ th of total services exports. Excluding the recent global financial crisis years, the strong demand over the past few years in developed economies has placed India among the fastest growing information technology markets in the world. With an 11 per cent share in India's services exports, travel and transportation services come next. On the imports side, about 44 per cent of India's services imports in 2010 came from the transportation services sector (Table 4). India's imports of transportation services heavily outweigh its exports. Therefore, transportation, computer and information technology services are two prominent sectors in India's services trade. At the same time, finance and insurance are also rapidly emerging as key services imports in India. Finally, India's services trade has been attached to a big surplus in computer services (US\$ 54 billion in 2010) and a high deficit in transportation services (US\$ 23 billion in 2010).

What are the factors driving such a rapid rise in India's services exports? Besides the important role played by the World Trade Organization (WTO) as an institution in promoting services trade, international exchange is increasingly taking the form of trade in services tasks as opposed to trade in goods, as the production process is divided into different parts that are performed in different locations, such as in India. ${ }^{6}$ Ghani and Kharas (2010) argued that India's 'services revolution' has been supported by deregulation of the services sectors. Telecommunication was substantially opened up to competition in the mid-1990s. Newer sectors, such as information technology (IT) and IT-enabled services (Business Process Outsourcing, Knowledge Process Outsourcing, and Business Transformation Services), are largely liberalized. Knowledge-based segments have been prominent among the fast growing services sectors, assisted by technological advances and a low-cost educated workforce with good English language capabilities. Noted in Mishra et al. (2011), technology has changed the very nature of the production frontier of services and in particular service exports, which has resulted in a rapid increase in the service exports and a growing share of services in GDP growth in India. This study also shows that service exports' sophistication is positively related to growth. Logistics services efficiency is one of the key drivers for attaining such services sophistication. However, there is no empirical evidence for any of the income groups (or geographical regions) as to whether logistics services efficiency plays a catalytic role in improving the merchandise trade flow and fragmentation of production across borders.

\footnotetext{
${ }^{6}$ Refer, for example, to Grossman and Esteban (2008a, 2008b)
} 
Unfortunately, it is not so easy for an economy to raise its international competitiveness in services trade. Trade in services is distinguished from trade in merchandise by the intangible and "disembodied" nature of many transactions. Unlike physical goods, which must cross borders and thus are subject to customs procedures and tariffs, services often involve direct transactions between the consumer and producer and do not necessarily cross a border. This fact complicates measurement of both services flows and their corresponding impediments. The challenge is thus to remove barriers to services trade. However, the measurement of impediments to services trade is problematic. ${ }^{7}$ Given severe data limitations, econometric studies on services trade and barriers are rare. A proper analysis of the barriers to India's services trade is essential to formulate appropriate trade policies in this sector. We make an attempt, despite tremendous data limitation, to assess barriers to India's services exports in the next few sections.

\section{Literature Review on Services Trade Barriers}

While the expanding importance of services in the economy has certainly been noticed, services trade does not figure prominently in research on economic growth and development. For example, growth theory accords no special role to services activities, with the exception of financial services (Marchetti and Ray, 2008). Trade theories have paid much greater attention to goods trade for the simple reason that most services were non-tradable for a long time (Mattoo et al., 2008). However, with the improvement in information and communication technology (ICT), trade in services has become significantly easier in the last couple of decades. A number of theoretical models have come up, which basically use the traditional comparative cost theories of either Ricardo or Heckscher-Ohlin to prove that liberalization of trade in services is welfare-improving for both the source as well as the recipient countries. In this study, we use a theoretically consistent gravity model to assess the barriers to India's services exports.

The gravity model has been used extensively in empirical international trade since it was introduced by Tinbergen (1962), a study that empirically showed that the trade between two countries was determined by their masses and distance between the two partners. ${ }^{8}$ Over time, this model has been used extensively in explaining the effects of different policies and other determinants of trade flows with the help of key variables related to economic size and distance. Its popularity in empirics increased rapidly with the introduction of a "theoretical"

\footnotetext{
7 Refer to Konan and Maskus (2006), Warren and Findlay (2000) and Hoekman (2000), which provides excellent surveys of these measurement issues. See also Brown and Stern (2001) and Stern (2002) for discussion of measurement and modelling in services.

${ }^{8}$ Drawing on an analogy from Newtonian physics, the gravity model was first introduced in economics by Tinbergen (1962). Poyhonen (1963) and Linnemann (1966) were the next two studies which attempted to explain trade flows by augmenting the gravity model. Since then, thousands of studies and analyses on international trade were carried out based on an augmented gravity model.
} 
gravity model by Anderson and van Wincoop (2003, 2004), which has become the de facto standard in empirical work. ${ }^{9}$

In contrast to the estimation approach to the analysis of trade costs, Jacks, Meissner, and Novy (2008) demonstrated that there is a simple analytical solution to the gravity model of Anderson and van Wincoop (2003), which allows for bilateral trade costs to be determined computationally instead of estimated. The solution to their "gravity redux" rests on the assumption that a country's total exports are inversely related to its trade barriers with other countries, which in turn is reflected in the amount of that country's trade within its own national boundaries, or economic activity. The equilibrium solution of their model yields a remarkably lean specification of the gravity model that can be solved directly for trade costs as a function of observable exports and income variables, and is suitable for direct calculation. More specifically, Jacks, Meissner, and Novy (2008) showed that an "iceberg" measure of bilateral trade costs $\left(\tau_{i j}\right)$ can be derived as the geometric average of the ratio of bilateral trade flows and the product of the countries' intra-national trade, defined as the share of tradable goods in national income net of total exports.

The gravity model literature on empirical international trade now covers a wide spectrum of trade flows and trade barriers. Nevertheless, most of it has focused on "policy" barriers, such as tariffs and non-tariff barriers, regional integration agreements, currency unions, the GATT/ WTO, time delays at export/import and trade facilitation, governance, corruption, and contract enforcement. On the other hand, very few have dealt with "non-policy" barriers, with the exception of Moreira et al. (2008); Francois, et al. (2009), Nordas and Piermartini (2004). To a large extent, "Gravity" has become the workhorse of empirical international trade.

The existing literature on the application of the gravity model to services trade is quite limited. The results of these studies vary greatly and are often contradictory. Some early papers on the subject were from Francois (1999), with the methodology further developed in Francois et al. (2003). Francois (1999) fit a gravity model to bilateral services trade for the United States and its major trading partners. The differences between actual and predicted imports were taken to be indicative of trade barriers. In another paper, Francois (2001) modeled the demand for imports of services as a function of the recipient country's GDP per capita and population, where the data on services trade flows are taken from the Global Trade Analysis Project (GTAP) database.

Grunfeld and Moxnes (2003) applied a gravity model to the bilateral export of services and FDI flow using data from the Organization for Economic Cooperation and Development (OECD, 2003). Regressors include the level of GDP and GDP per capita in the importing and exporting countries, the distance between them, a dummy variable if they are both members of a regional trade area (RTA), a measure of corruption in the importing country, and a trade

\footnotetext{
${ }^{9}$ Anderson (1979) first attempted to provide a theoretical foundation to the gravity model. Since our objective is to estimate trade potential using the gravity model, a detailed discussion on the evolution of the gravity model is thus beyond the scope of our analysis.
} 
restrictiveness index to measure the barriers to services trade in the importing country. The results suggest that the standard gravity model effects found in studies on trade in goods apply to services as well. Trade in services between two countries is positively related to their size and negatively related to the distance between them and barriers to services. They found that the presence of RTA is not significant in the case of services.

Kimura and Lee (2006) applied the gravity framework to services trade with the aim of comparing the results to the estimates for trade in goods. As in Grunfeld and Moxnes (2003), they used OECD statistics on trade in services. Kimura and Lee (2006) estimated their gravity equation using a mixture of OLS and time-fixed effects. The major difference they found is that distance between countries is more important in services trade than goods trade. They suggest that there are higher transport costs for services but fail to provide any reason why this may be the case. Common language between the importer and the exporter is not found to be significant. This last result differs from Park (2002), who using data from GTAP, finds language to positively influence trade in several service sectors. Kimura and Lee (2006) found that RTA membership is positively correlated with trade, which contradicts the findings of Grunfeld and Moxnes (2003). The authors argue that while many RTAs do not explicitly cover trade in services, their presence may indirectly facilitate the process. Lejour and de Paiva Verheijden (2004) also compared gravity model estimates for trade in goods and services, examining intra-regional trade in Canada and the European Union (EU) employing the OECD services trade statistics used in the above studies and data from the official Canadian statistical agency. Unlike Kimura and Lee (2006), distance was found to be less important in Lejour and de Paiva Verheijden (2004) for services compared to goods.

The opposing nature of the results regarding the importance of distance in services trade is reflected elsewhere in the literature. Portes and Rey (2005) examined international equity flows and found distance to be negative and significant, which they note is counter-intuitive given the weightlessness of the commodity. Overlaps in time zones were also included, with the reasoning that countries with similar opening hours should trade more. This variable was positive and significant. They argued that distance proxies for informational frictions that restrict international equity flows. Park (2002) also found distance to be negative and statistically significant across all service sectors examined. Tharakan et al. (2005) found distance to be insignificant in comparing Indian software exports to overall goods trade flows.

Finally, trade liberalization is primarily limited to tariff reduction on commodities. The literature shows that little attention has been paid to the significant gains from a reduction in trade costs by the elimination of regulatory costs and time delays and the improvement of services infrastructure, among others things, in India. Thus, this study makes an attempt to understand the barriers to services exports in India. 


\section{The Three-Stage Gravity Model and Data}

Trade costs matter but are difficult to measure (Anderson and van Wincoop, 2004). Any attempt to measure trade costs needs consistent observable data, which in many cases are not available. To overcome this limitation, Anderson and van Wincoop (2003) derived a theoretically consistent gravity model to infer unobservable trade costs directly from observable trade flows. In this study, we consider a world of $N$ countries and a continuum of differentiated services. We assume that countries specialize in a range of services and that consumers have constant elasticity of substitution (CES) preferences. ${ }^{10}$ Also, we assume the existence of the simplifying assumptions of a one-sector economy with consumers holding constant elasticity of substitution preferences, and common elasticity among all homogenous goods. The gravity model for using panel data of exports from economy $i$ to economy $j\left(X_{i j}\right)$ takes the following shape:

$$
X_{i j}=\frac{Y_{i} Y_{j}}{Y^{w}}\left(\frac{t_{i j}}{\prod_{i} P_{j}}\right)^{1-\sigma}
$$

where $Y_{i}$ and $Y_{j}$ are the income levels of countries $i$ and $j, Y_{w}$ is total world income, and $\sigma>1$ is the elasticity of substitution. The trade cost factor, $t_{i j} \geq 1$, is defined as the gross bilateral cost of importing services so that if $p_{i}$ is the supply price of a service produced in country $i$, then $p_{i j}=t_{i j} p_{i}$ is the price faced by consumers in country $j . \Pi_{i}$ and $P_{j}$ are country $i$ 's outward and country $j$ 's inward multilateral resistance terms, respectively. These capture each country's average international trade barriers. An important insight of the model is that bilateral services trade flows, $X_{i j}$, depend on the bilateral trade barrier $t_{i j}$ relative to average international trade barriers. Taking the natural log of equation (1) and applying it to sector $k$, we obtain

$$
\operatorname{In}\left(X_{i j}^{k}\right)=\operatorname{In}\left(Y_{j}^{k}\right)+\operatorname{In}\left(Y_{i}^{k}\right)-\operatorname{In}\left(Y_{w}^{k}\right)+\left(1-\sigma_{k}\right) \operatorname{In}\left(t_{i j}^{k}\right)-\left(1-\sigma_{k}\right) \operatorname{In}\left(P_{j}^{k}\right)-\left(1-\sigma_{k}\right) \operatorname{In}\left(\prod_{i}^{k}\right)+e_{i j}^{k}
$$

where $Y_{i}^{k}$ is the output of economy $i$ in sector $k, Y_{j}^{k}$ is the output of economy $j$ in sector $k, Y_{k}^{w}$ is aggregate (world) output in sector $k, \sigma_{k}$ is elasticity of substitution in sector $k$ (intra-sectoral elasticity of substitution between varieties), $t_{i j}{ }^{k}$ is trade costs facing exports from economy $i$ to economy $j$ in sector $k$, and $e^{k}{ }_{i j}$ is the random error term, satisfying the usual assumptions.

\footnotetext{
${ }^{10}$ We assume all services are differentiated by place of origin and each country specializes in the production of only one service. Therefore, supply of each service is fixed $(n=1)$, but it allows preferences to vary across countries subject to the constraint of market clearing (CES).
} 


$$
\begin{gathered}
P_{j}^{k}=\sum_{i=1}^{N}\left\{\frac{t_{j}^{k}}{\prod_{i}^{k}}\right\}^{1-\sigma_{k}} \frac{Y_{i}^{k}}{Y_{w}^{k}} \\
\prod_{i}^{k}=\sum_{i=1}^{N}\left\{\frac{t_{j}^{k}}{P_{j}^{k}}\right\}^{1-\sigma_{k}} \frac{Y_{j}^{k}}{Y_{w}^{k}}
\end{gathered}
$$

Here, equation (3) presents an inward resistance term which shows country $j$ 's imports from country $i$ depend on trade costs across all suppliers. An outward resistance term in equation (4), by contrast, captures the dependence of exports from $i$ to $j$ on trade costs across all importers."

Before implementing this model in an empirical setting, we need to specify bilateral trade costs $t_{i j}$ in terms of observable variables. We assume from equation (2) that $t_{i j}$ captures several trade costs components and other border effects. We therefore introduce bilateral trade cost components ${ }^{12}$, namely, $t c^{k}{ }_{i j}$. Assuming a monopolistically competitive market, the term $(1-\sigma)$ should be negatively related to the volume of trade. Additional factors are captured using a set of bilateral (economy- pair) fixed effects $\left(\alpha_{i j}\right)$.

$$
\operatorname{In}\left(t_{i j}^{k}\right)=\beta_{1} \operatorname{In}\left(t c_{i j}^{k}\right)+\sum_{i \neq j} \alpha_{i j}
$$

Substituting (5) with (2) and including sector fixed effects in addition to economy-pair fixed effects gives our baseline estimating equation:

$$
\operatorname{In}\left(X_{i j}^{k}\right)=\sum_{i \neq j} \alpha_{i j}+\beta_{1} \operatorname{In}\left(Y_{i}\right)+\beta_{2} \operatorname{In}\left(Y_{j}\right)+\beta_{3} \operatorname{In}\left(t c_{i j}^{k}\right)+\beta_{5} \ln \left(D_{i j}\right)+\sum \gamma_{k}+e_{i j}^{k}
$$

where $D_{i j}$ is the bilateral distance between countries $i$ and $j, \gamma$ is the set of exogenous variables, and $e$ is the random error term.

Therefore, trade is a product of the scale and structure of partner economies, their geographic, political, and institutional proximities; openness of their economies to trade; and trade barriers. In our particular case, the final estimated equation, modifying equation (6) suitably, takes the following shape.

$$
\operatorname{In}\left(X_{i j}\right)=\sum_{i \neq j} \alpha_{i j}+\beta_{1} \operatorname{In}\left(G D P_{i}\right)+\beta_{2} \operatorname{In}\left(G D P_{j}\right)+\beta_{3} \ln \left(D_{i j}\right)++\sum_{m} \lambda_{m} B+\sum_{k} \delta_{k} C+\sum_{l} \phi_{l} Z_{i j}+e_{i j}
$$

\footnotetext{
${ }^{11}$ The usual caveat is that these so-called multilateral resistance terms (MRTs) are not always directly observable. Several alternative ways of proxying for MRTs are possible. For further details, refer to WTO (2012)

${ }^{12}$ In literature, this term is also referred to as trade barriers.
} 
where GDP is the gross domestic product, taken at current US Dollar, $B$ is the set of services trade barrier variables, $C$ is the set of control variables, and $Z$ is the set of binary variables. To control for country-level heterogeneity, we introduce country dummies in equation (7). The dummies are as follows: $A D J$ is a binary variable to identify a pair of countries that are geographically adjacent, contiguous, or share a border ( $=1$ if they are adjacent, 0 otherwise), $L A N$ is a binary variable to capture language similarity between a pair of countries ( $=1$ if they have language similarity, $O$ otherwise), $R T A$ is a binary variable which represents if a pair of countries have any regional trading arrangement in the form of the PTA/FTA, and $L L D$ is a landlocked dummy ( $=1$ if country is landlocked, 0 otherwise).

We use the gravity model in equation (7) to analyze the trade flows, and the coefficients thus obtained are then used to assess services trade barriers under various scenarios. The augmented gravity model is estimated using a panel dataset for the years, 2000 2006. The data for the gravity model are collected from several secondary sources and taken in bilateral pairs.

The primary source of services trade data used in this analysis is Statistics on International Trade in Services, assembled by the OECD (2003). This covers imports and exports of services between 27 OECD countries and up to 55 non-OECD partner countries. The collection of the data is based on the Manual on Statistics of International Trade in Services guidelines, which extend the International Monetary Fund (IMF) balance of payments methodology to account more fully for service transactions.

Our methodological approach imposes the assumption that the error terms are normally distributed. However, this assumption is often violated in large datasets where the error term is heteroskedastic. We thus use robust standard errors without specifying a cluster group in all of the regressions.

\section{Robustness}

These relationships cannot be interpreted as causal until we rule out the possibility of endogeneity in equation (7). To address this problem, we use a dynamic Hausman-Taylor estimation to analyze changes across countries and over time.

Recognizing the nature of trading flows between countries as relationships that develop and change over time has resulted in an increasing use of panel data approaches in the estimation of gravity models. Such a method is chosen in this study. The use of different panel data methods, such as random, fixed effects, or Hausman-Taylor estimators, allows for various assumptions regarding trade flows to be analyzed and tested. In particular, in a panel data analysis of gravity models, possible heterogeneity and endogeneity issues can be examined by isolating country pair effects (factors that influence trade between two countries). As Egger and Nelson (2006) 
showed, this allows the analysis of what they describe as between-country pair effects (the cross sectional element) and within-country pair effects (the time series element).

Equation (7) has been estimated using the Hausman-Taylor model (HTM) with the dependent variable of services exports between India and its partner countries. A cross-section model does not explain the variance in bilateral trade flows when we have a time-specific impact on trade flows. Since there are significant and systematic variations of export patterns across trade partners, a satisfactory model of bilateral exports should explain substantial heterogeneity of exports at the country level. We, therefore, use panel data since it can better explain the relevant relationships between trade flows and trade barriers over time when we have both time-variant and time-invariant exogenous variables. We use individual country effects interchangeably in the model.

The HTM fits panel-data random-effects models in which some of the covariates are correlated with an unobserved individual-level random effect. The estimators, originally proposed by Hausman and Taylor (1981) and Amemiya and MaCurdy (1986), are based on instrumental variables. Although the estimators implemented in HTM use the method of instrumental variables, each command is designed for different problems. The HTM estimators that are implemented assume that some of the explanatory variables are correlated with the individual-level random effects, $u[i]$, but that none of the explanatory variables are correlated with the idiosyncratic error $e[i, t]$.

It is also worth noting that the fixed effects approach does not allow for estimating coefficients on time invariant variables, such as distance or common language dummies, though the consistent estimation of such effects is equally important in many situations. Cheng and Wall (2005) simply suggest estimating the regression of the (estimated) individual effects on individual-specific variables by the OLS, though this approach clearly ignores the potential correlation between individual specific variables and (unobserved) individual effects such that the resulting estimates are likely to be severely biased. In order to properly address this issue, we need to employ the HTM estimation technique. Most recent empirical studies also emphasize the importance of explicitly allowing for the presence of time-specific effects in order to capture business cycle effects.

According to Cheng and Wall (2005), the OLS suffers from heterogeneity bias in the gravity model context. Trade between any pair of countries is likely to be influenced by certain country-specific unobserved information (country effects). However, these country effects appear to be correlated with explanatory variables, thus making the OLS a biased estimator. The explanatory variables are considered to be endogenous as they are correlated with the error term. To overcome these shortcomings, according to Egger $(2002,2005)$, the HTM is the most appropriate estimator for trade in goods and services. The HTM employs an instrumental variable approach that uses information solely from within the dataset to eliminate the correlation between explanatory variables and the unobserved individual effects that undermine the appropriateness of the random effects model in the gravity model context. The HTM is 
increasingly applied in gravity models of trade in goods and services. ${ }^{13}$ This also resolves the endogeneity problem.

\section{Measuring Services Trade Facilitation}

Barriers to trade interfere with the ability of firms from one country to compete with firms from another (Deardorff and Stern, 2008). Deardorff (2001) argued that international trade patterns depend more on unobservable trade transaction costs than on factor endowments and technology. The underlying assumption of the majority of the models is that trade barriers affect transaction costs in both trade and production. In a developing country context, services trade restrictiveness is important, and in some literature it has been termed as a barrier similar to tariffs on goods. ${ }^{14}$ However, supply-side bottlenecks (e.g. trade barriers) are equally important, the removal of which would lead to increased services trade. We, in this study, construct an index which captures some important trade facilitation elements that influence the services trade flows between countries.

A country may have a rich network of telecommunication services but a banking infrastructure that is undeveloped, for example. Therefore, the statistical technique of principal component analysis (PCA) becomes handy in constructing a unique single index that captures the variance or information contained in different variables capturing different aspects of infrastructure. We follow equation (8) to build the Services Trade Facilitation Index (STFI).

$$
S T F I_{i t}=\sum W_{j t} X_{j i t}
$$

where $S T F I_{i t}$ is the services trade facilitation index of the $i$-th country in $t$-th time, $W_{j t}$ is the weight of the $j$-th aspect of services trade facilitation indicator in $t$-th time, and $X_{j i t}$ is the value of the $j$-th aspect of the services trade facilitation indicator for the $i$-th country in $t$-th time point. The PCA finds linear combinations of the original variables to construct the principal components or factors with a variance greater than any single original variable.

Here, the Services Trade Facilitation Index (STFI) is comprised of five indicators, viz. (i) internet users (per 100 people) (tnt_usr) (ii) international internet bandwidth (bits per person) (int_bw), (iii) electric power consumption (kWh per capita) (pce), (iv) air transport passengers carried (per 100 people) (air_p), and (v) fixed line and mobile phone subscribers (per 100 people) (tel). Each of the five services trade facilitation indicators is normalized for the size of the economy so that it is not affected by the scale. The weights $\left(W_{j t}\right)$ are calculated by dividing

\footnotetext{
${ }^{13}$ Refer, for example, Egger and Pfaffermayr (2004) applied HTM to FDI flows.

${ }^{14}$ Refer, for example, to Mattoo et al. (2008)
} 
the rotated factor loading of any variable by the sum of rotated factor loadings. Thus, weights make intuitive sense as they express the contribution of each variable to the total variance of the common factor (STFI in this case). The data sources include issues of the World Bank's World Development Indicators 2010 (World Bank, 2010). The estimated index is provided in Table 5 and Appendix 1 provides the corresponding PCA weights. The following observations are worth noting.

First, among India's 33 services trade partners, developed and developing economies occupy the top and bottom positions in STFI, respectively. Their relative ranks over time did not change much barring a few countries such as Belgium, Ireland, and Japan. ${ }^{15}$ This fact directly suggests that there has not been any major change in services trade facilitation among India's major services trade partners. However, this is not to deny that there was a slight change in the services trade facilitation level when comparing the year 2000 with $2006 .{ }^{16}$ Nevertheless, higher income countries have better infrastructures (represented by STFI), compared to lower or middle income countries. The performance of the countries in services trade facilitation between the years, $2000 \sim 2006$ has improved (better fit in 2006 in Figure 1). The correlation is positive in both of the years (Figure 1). Services trade facilitation is also positively associated with services exports. Countries with higher per capita income and higher services exports are endowed with better services trade facilitation, and their associations have remained unchanged over time (Figure 2).

Second, performance in services trade facilitation varies across countries (Table 6). For example, the Netherlands in Internet users, Denmark in Internet bandwidth, Norway in electric power consumption, Ireland in air passengers, and Luxembourg in telephone ranked first in 2006. India's global rank has remained static over time, thus suggesting ample scope for improvement.

Third, access to Internet, telephone, and electricity are three important factors that influence the indexation compared to other indicators over time (see Appendix 1). While country performance in Internet users or telephone are relatively balanced relative to other indicators, the same in Internet bandwidth, electric power consumption or air passengers are skewed towards the top 11-12 countries.

Therefore, the foregoing analysis, which presents services trade facilitation indicators and global ranks of countries, clearly indicates that performance is mixed and varied across countries. In general, countries are characterized by a lack of infrastructure relating to services trade. Services trade facilitation indicators focus on both the policy and market structure, where the private sector is the main service provider. The assessment of the services barriers through

\footnotetext{
${ }^{15}$ Rank correlation remained static (0.98) over time from 2000 to 2006, and significant at a 1 per cent level.

${ }^{16}$ The rank correlation coefficient was 0.94 .

${ }^{17}$ This, however, does not indicate any causal relation, nor its direction of movement.

${ }^{18}$ The number of countries above median was 17 in Internet users, 12 in Internet bandwidth, 12 in electric power consumption, 11 countries in air passengers, and 21 in Telephone.
} 
the PCA thus reflects a variety of barriers might influence the trade flow, which we test in the next section.

The quality and performance of the services trade sectors differ markedly across countries, and more prominently between developed and developing countries. These variations stem from differences in the quality and cost of infrastructure services as well as differences in policies, procedures, and institutions. Surely, they have a significant effect on trade competitiveness and market access.

\section{Do Barriers Matter for Services Exports?}

While there is strong anecdotal evidence that the lack of adequate trade infrastructures might have altered trade potential due to a rise in trade costs, we try to assess the effect of trade facilitation/trade costs elements on bilateral trade with the help of an augmented gravity model. This study uses an augmented gravity model (Anderson and van Wincoop type) and then determines important trade remedies. ${ }^{19}$ The ordinary least squares (OLS) regressions are based on panel data, where all the variables are taken for the years from 2000 to 2006 . We use a threestage regression process to understand the impact of trade facilitation comprising several services trade facilitation indicators, and it shows that it captures essentially all the explanatory power of the indicators used separately. Definitions of variables and corresponding data sources are detailed in Appendix 2, while the list of partner countries of India is presented in Appendix 3.

Under what conditions will OLS estimates of the gravity model be statistically significant? $^{20}$ To have OLS estimates become consistent, unbiased, and efficient within the class of linear models, basic econometric theory lays down the following three necessary and sufficient conditions: first, the errors $\left(e_{i j}\right)$ must have zero means and be uncorrelated with each of the explanatory variables (the orthogonality assumption); second, the errors $\left(e_{i j}\right)$ must be independently drawn from a normal distribution with a given (fixed) variance (the homoskedasticity assumption); and third, none of the explanatory variables is a linear combination of other explanatory variables (the full rank assumption). To test the aforementioned three properties, we therefore carry out the following basic diagnostics: (i) statutory hypothesis tests (F-test) are carried out on the parameter estimates; (ii) a Ramsey test is done to check model specification; (iii) normality of residuals is tracked through a Kernel density plot; (iv) all estimates are checked for heteroscedasticity through Cameron and Trivedi's decomposition of IM-test; (v) multicollinearity problems are checked by looking

\footnotetext{
${ }^{19}$ Since the objective is to assess the effect of trade barriers using the gravity model, a detailed discussion on the evolution of the model is thus beyond the scope of this paper.

${ }^{20}$ Refer, for example, to Shepherd (2012), for a detailed discussion on this.
} 
at the variance inflation factor (VIF); and (vi) Durbin-Watson statistic was used to check any presence of serial correlation.

Appendix 4 presents some of the basic facts about the variables (taken in log scale). Most of the data do not show large variations as given by standard deviations. However, there is a strong correlation among some of the variables ${ }^{21}$, and at the same time there are some variables (for example, export) that are not highly correlated with independent variables. The initial augmented gravity results are presented in Table 7 . The following observations are worth noting.

First, specification 1 in Table 7 contains the initial set of models fitted, before any of the trade facilitation or logistics indicators or additional variables are included. Specification 1 contains regressions of bilateral trade on GDP in the exporting and importing countries, while specification 2 shows the simple gravity model with distance. Specifications 3 and 4 represent augmented gravity models with market size (GDP) and consumption power (GDP per capita), along with dummies which might influence trade flows between countries. Specifications 5 12 in Table 7 include, one at a time, the set of services trade facilitation indicators. Distance, language, and landlocked dummies, and the GDPs of exporting and importing countries are statistically significant and have the correct sign in all the specifications in Table 7. The dummy variable representing regional trade agreements (RTAs), including bilateral FTAs, is not significant but has appeared with correct (positive) signs, except in model 8. Among the services trade facilitation indicators, we found the partner country's (i) air transportation infrastructure, (ii) information and technology quality, (iii) regulatory quality, and (iv) overall competitiveness are statistically significant. The rest of variables are not statistically significant and show no statistical relation with services trade flows. Therefore, it can be said that most of the services trade facilitation indicators have a significant effect on bilateral trade between India and her partner countries in the expected direction.

Second, most of the specifications in Table 7 explain over 50 per cent of the variability in bilateral trade, thereby showing a considerably good fit. However, some of the specifications in Table 7 slightly suffer from omitted variable bias, such as specifications 1 to 4 . Hence, we can conclude that India's services trade is very much contingent upon trade facilitation.

We now select the set of those services trade facilitation indicators shown to be significantly related to bilateral trade in Table 7 in the remaining gravity analysis. Table 8 includes these critical services trade facilitation and logistics indicators, along with the standard variables described earlier. Based on the finding by de Groot et al. (2004) and motivated by Rodrik et al. (2002) that institutional quality is important in explaining bilateral services trade flows, the Control of Corruption is added to the model to represent institutional quality for both the exporting and the importing country (Table 8). The STFI better represents the functional relation between bilateral exports and aforementioned explanatory variables. A three-stage

\footnotetext{
${ }^{21}$ Due to space constraints, we ignore reporting the correlation coefficient index. The same may be available from author on request.
} 
augmented gravity estimation is then selected for the remaining part of the analysis.

Here, the STFI (through regressions) for Indian exports is estimated in three stages. The first stage involves fitting a simple gravity model that includes most of the standard variables in Table 8. The second stage attempts to explain the residuals of the first-stage regression using services trade facilitation indicators, which represent components of trade costs, such as services trade infrastructure and distance (a surrogate for a trade barrier). The second-stage regression derives the optimal coefficients (weights) for these variables to best explain the residuals from the first stage. If the components of these variables are important determinants of bilateral trade, this second-stage regression would be expected to have a statistically significant explanatory power. The third stage uses the coefficients derived in the second stage to create a single STFI in an augmented gravity model. If this single index performs reasonably well in explaining bilateral trade flows, it can then be argued that the index systematically captures the various components of total trade cost. To find out the relative robustness, we also use a constructed STFI based on principal component analysis in Section VI.

Table 8 shows the results of these three stages. The second-stage adjusted $R^{2}$ is 0.418 , clearly highly significant. The third stage (I) augmented gravity model using the single STFI together with the first-stage variables explains 55 per cent of the variability in bilateral trade. The results were also improved in the third stage (I). Therefore, the single STFI successfully replaces several separate services trade facilitation indicators.

The gravity model with the STFI can be used to evaluate the effectiveness of initiatives to improve services logistics and to help guide the allocation of resources to and deployment of such initiatives. For example, India has to reduce trade transaction costs by removing barriers to services trade. Countries can tackle transaction costs through improved services trade infrastructures, which are responsible for faster movement of services across the countries, and good institutional quality.

However, the aforementioned analysis may suffer from endogeneity. As discussed before, we use the HTM. The estimated results for total services exports are presented in Table 9. Estimated coefficients in the HTM appear with correct signs. The size of importing countries' incomes strongly determines exports of services from India. Apparently, a 1 per cent rise in the importing country's market size (income) would lead to a 3 to 4 per cent rise in India's export of services (Table 9).

The stock of India's services trade facilitation positively affects India's services exports. It is not surprising to note that India suffers tremendously from poor quality of services trade infrastructure. The estimated results show that a 1 per cent improvement in services trade facilitation measures would lead to 2 per cent rise in services exports in India. At the same time, India's partner countries' services trade infrastructures are relatively insignificant, so an exporting country's services trade infrastructure is more important than that of the importing country. Bilateral distance has a strong negative influence on services export. The shorter the distance between each pair of partners, the higher the services export. 
Finally, drawing from past literature, a comprehensive measure of trade costs is derived from a theory-founded gravity model of international trade. This section calculates the need for improved services trade facilitation. The analysis reveals that better services trade facilitation in exporting countries would help increase India's services trade.

The HTMs are a relatively better fit (Wald $\chi^{2}$ statistically significant at the 1 per cent level). However, the good fit in the HTM tells us that services trade barriers influence the services exports, of which distance between India's services trade partners is the most important. This indirectly also suggests a strong presence of unobserved trade costs that are negatively affecting India's services exports.

\section{Conclusions and Policy Implications}

In this study, we have performed an empirical analysis of the linkages between India's services trade flow and the barriers it faces. The results of the analysis show that the linkages between services exports and services trade barriers are multiple and complex. The study indicates that the income of the partner country (importing country) is crucial for services exports from India. The findings of this paper suggest that improved services trade facilitation helps unlock unrealized trade potential; more effective policy approaches toward improved trade infrastructure are, therefore, needed to facilitate services exports from India. The results make it abundantly clear that services trade facilitation reform is a key factor affecting services exports from India. Intuitively, it can be said that India can expand its services exports by signing MRAs on professional qualification with partner countries, particularly with developed countries where India's services export market is largely concentrated. India may also ask its trading partners (or region) to relax barriers on services exports, such as stringent visa regulations for services professionals in the IT sector, aviation tax on air services, foreign ownership caps, restrictions on types of commercial presence, discriminatory registration requirements and licensing procedures, nationality and residency requirements, economic needs tests, and discriminatory treatment advantaging domestic companies over foreign ones, to mention a few. Prolonged barriers on services exports lead to India having a large trade imbalance, as happened with China.

Two sectors are very important for India: software and information technology (in exports) and transportation services (in imports). Recreating favourable domestic policies that are responsible for services trade facilitation and reforming domestic regulations in trade and infrastructure sectors in tandem need the utmost attention. Domestic regulations behave like pseudo tariffs in services, such as restrictions on the inter-state movement of goods and services (in case of transportation services) and lack in proper competition policy (in the case of software and information technology services). Strong and unfriendly regulations are highly 
detrimental to the expansion or diversification of services trade. Therefore, we need to intensify reforms in domestic regulations.

This analysis also calls for a sectoral analysis in order to understand the intensity of trade barriers, particularly for services sectors which serve as vital inputs for producing other goods and services, and are crucial for the overall growth of the Indian economy. More research is also needed on the interaction between services trade policies and regulation.

This study is not without limitations, and a number of issues require further consideration. First, future studies are needed to understand the relationship between disaggregated services trade facilitation indicators and services trade flows. Second, an analysis of the causality between services exports and services trade barriers, such as the STFI, would also be worth presenting. Third, the analysis presented in this paper may need to be verified with new STF indicators from alternative sources. Fourth, one should make an attempt to estimate tariff equivalents of the STFI. Fifth, a more sophisticated dynamic analysis could be attempted to verify the findings of this paper.

Received 30 October 2011, Revised 9 November 2012, Accepted 3 December 2012 
Figure 1. Services Trade Facilitation and GDP per capita
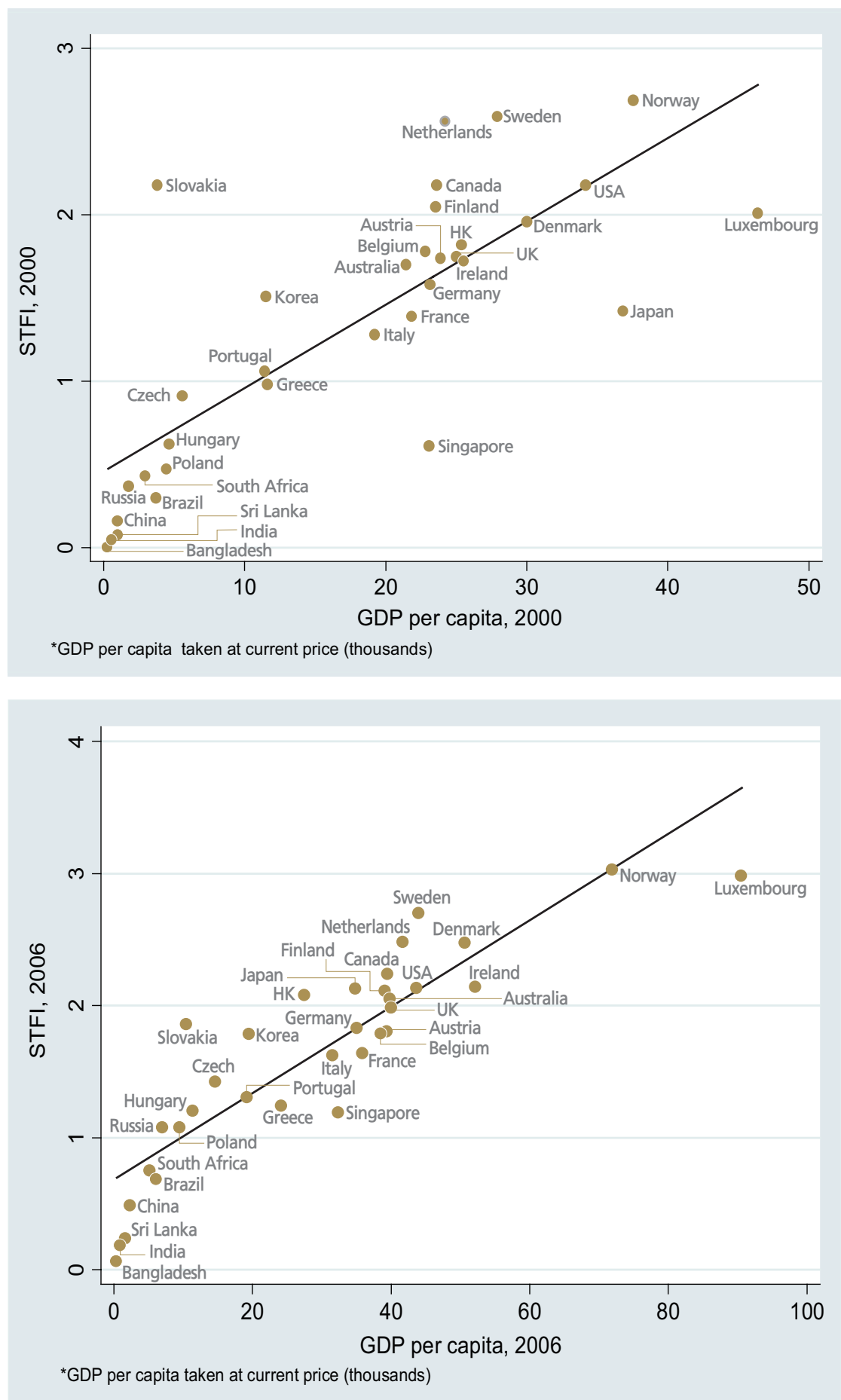
Figure 2. Services Trade Facilitation, GDP per capita and Services Export
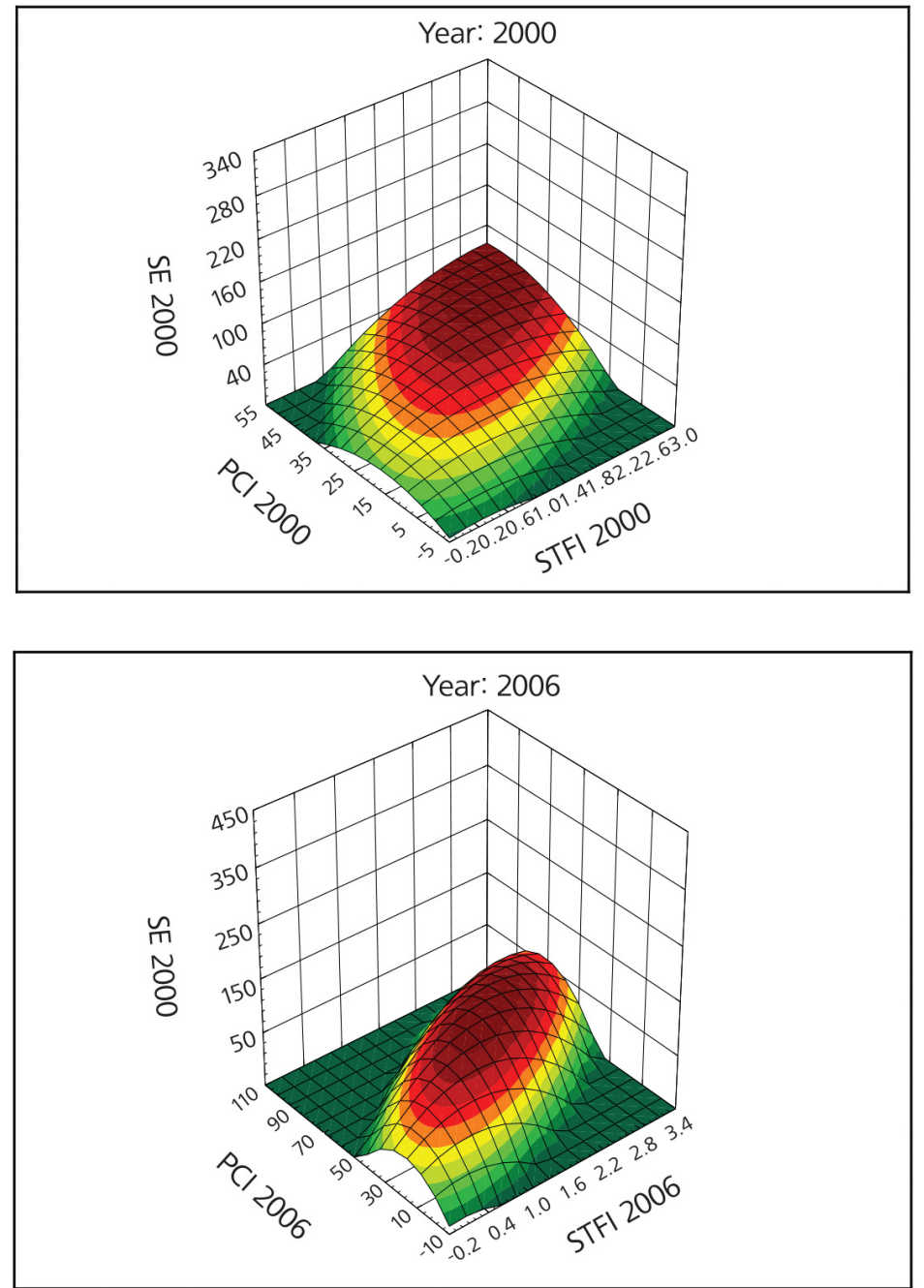

(Note) SE : Services export

STFI : Services Trade Facilitation Index

PCI : GDP per capita 
Table 1. India's Services Trade Growth

\begin{tabular}{|c|c|c|c|c|c|c|c|}
\hline \multirow[b]{3}{*}{ Year } & \multicolumn{3}{|c|}{ World } & \multicolumn{4}{|c|}{ India } \\
\hline & Export & Import & Total & Export & Import & Total & $\begin{array}{c}\text { Share in } \\
\text { World }\end{array}$ \\
\hline & \multicolumn{3}{|c|}{ (US\$ billion) } & \multicolumn{3}{|c|}{ (US\$ billion) } & $(\%)$ \\
\hline 1991 & 870.33 & 916.20 & 1786.53 & 4.93 & 5.95 & 10.88 & 0.61 \\
\hline 2000 & 1529.34 & 1538.37 & 3067.71 & 16.69 & 19.19 & 35.88 & 1.17 \\
\hline 2001 & 1535.80 & 1559.15 & 3094.95 & 17.34 & 20.10 & 37.44 & 1.21 \\
\hline 2010 & 3745.44 & 3560.10 & 7305.54 & 116.32 & 108.59 & 224.91 & 3.08 \\
\hline \multicolumn{8}{|c|}{ Compound annual growth rate $(\%)$} \\
\hline $1991-2000$ & 5.80 & 5.32 & 5.56 & 12.97 & 12.42 & 12.67 & 6.74 \\
\hline $2001-2010$ & 9.32 & 8.61 & 8.97 & 20.97 & 18.38 & 19.64 & 9.79 \\
\hline
\end{tabular}

(Source) Calculated based on UNCTAD Statistics

Table 2. Trends in India's Services Exports and Imports

\begin{tabular}{|c|c|c|c|c|c|c|}
\hline \multirow{2}{*}{ Year } & \multirow{2}{*}{$\begin{array}{c}\text { Services } \\
\text { Trade Share } \\
\text { in GDP }\end{array}$} & Volume & $\begin{array}{c}\text { Share in } \\
\text { World }\end{array}$ & Volume & $\begin{array}{c}\text { Share in } \\
\text { World }\end{array}$ & $\begin{array}{c}\text { Imports } \\
\text { Trade }\end{array}$ \\
\cline { 3 - 6 } & $(\%)$ & (US\$ billion) & $(\%)$ & (US\$ billion) & $(\%)$ & (US\$ billion) \\
\hline $1990-91$ & 3.381 & 4.551 & 0.557 & 3.571 & 0.708 & 0.98 \\
\hline $1995-96$ & 4.799 & 7.344 & 0.547 & 7.544 & 0.827 & -0.20 \\
\hline $2000-01$ & 7.843 & 16.268 & 1.092 & 14.576 & 1.265 & 1.69 \\
\hline $2001-02$ & 7.859 & 17.140 & 1.128 & 13.816 & 1.316 & 3.32 \\
\hline $2002-03$ & 7.962 & 20.763 & 1.195 & 17.120 & 1.299 & 3.64 \\
\hline $2003-04$ & 8.176 & 26.868 & 1.256 & 16.724 & 1.393 & 10.14 \\
\hline $2004-05$ & 8.460 & 46.031 & 1.230 & 31.832 & 1.332 & 14.20 \\
\hline $2005-06$ & 8.894 & 60.610 & 1.281 & 38.345 & 1.355 & 22.27 \\
\hline $2009-10$ & 12.356 & 161.25 & 2.076 & 82.33 & 1.830 & 78.92 \\
\hline
\end{tabular}

(Source) Calculated based on RBI (2011) 
Table 3. Composition of India's Services Exports

\begin{tabular}{|c|c|c|c|c|c|c|c|}
\hline \multirow{3}{*}{ Major components } & Volume & Share* & Volume & Share* & Volume & Share* & \multirow{2}{*}{$\begin{array}{l}\text { CAGR } \\
(2000- \\
2010)\end{array}$} \\
\hline & 2000 & 2000 & 2005 & 2005 & 2010 & 2010 & \\
\hline & $\begin{array}{c}\text { (US\$ } \\
\text { billion) }\end{array}$ & (\%) & $\begin{array}{c}\text { (US\$ } \\
\text { billion) }\end{array}$ & $(\%)$ & $\begin{array}{c}\text { (US\$ } \\
\text { billion) }\end{array}$ & (\%) & (\%) \\
\hline Transportation & 1.98 & 11.86 & 5.75 & 10.95 & 13.25 & 10.70 & 18.87 \\
\hline Travel & 3.46 & 20.74 & 7.49 & 14.26 & 14.16 & 11.44 & 13.67 \\
\hline Communications Services & 0.60 & 3.59 & 1.57 & 2.98 & 1.41 & 1.14 & 8.10 \\
\hline Construction Services & 0.50 & 3.01 & 0.35 & 0.66 & 0.52 & 0.42 & 0.40 \\
\hline Financial Services & 0.28 & 1.65 & 1.14 & 2.18 & 6.00 & 4.85 & 32.31 \\
\hline Insurance Services & 0.26 & 1.54 & 0.94 & 1.79 & 1.78 & 1.44 & 19.25 \\
\hline $\begin{array}{l}\text { Computer and Information } \\
\text { Services, of which }\end{array}$ & 4.73 & 28.33 & 21.87 & 41.64 & 56.70 & 45.81 & 25.34 \\
\hline Computer Services & 4.63 & 27.76 & 21.71 & 41.33 & 56.11 & 45.34 & 25.45 \\
\hline Information Services & 0.09 & 0.57 & 0.16 & 0.31 & 0.59 & 0.48 & 18.11 \\
\hline $\begin{array}{l}\text { Personal, Cultural, and } \\
\text { Recreational Services }\end{array}$ & 0.01 & 0.06 & 0.11 & 0.21 & 0.33 & 0.27 & 37.59 \\
\hline Services Export Total & 16.69 & & 52.53 & & 123.76 & & 19.98 \\
\hline
\end{tabular}

(Note) * : Share in total services exports, CAGR : Compound annual growth rate

(Source) Calculated based on IMF (2011)

Table 4. Composition of India's Services Imports

\begin{tabular}{|c|c|c|c|c|c|c|c|}
\hline \multirow{3}{*}{ Major components } & Volume & Share* & Volume & Share* & Volume & Share* & \multirow{2}{*}{$\begin{array}{l}\text { CAGR } \\
(2000- \\
2010)\end{array}$} \\
\hline & 2000 & 2000 & 2005 & 2005 & 2010 & 2010 & \\
\hline & $\begin{array}{c}\text { (USS } \\
\text { billion) }\end{array}$ & $(\%)$ & $\begin{array}{c}\text { (US\$ } \\
\text { billion) }\end{array}$ & $(\%)$ & $\begin{array}{c}\text { (US\$ } \\
\text { billion) }\end{array}$ & (\%) & $(\%)$ \\
\hline Transportation & 8.70 & 45.36 & 20.68 & 43.73 & 36.36 & 44.05 & 13.88 \\
\hline Travel & 2.69 & 14.02 & 6.19 & 13.08 & 9.41 & 11.40 & 12.06 \\
\hline Communications Services & 0.10 & 0.55 & 0.42 & 0.88 & 1.19 & 1.45 & 24.76 \\
\hline Construction Services & 0.13 & 0.66 & 0.60 & 1.27 & 0.99 & 1.20 & 20.53 \\
\hline Financial Services & 1.28 & 6.66 & 0.87 & 1.84 & 6.79 & 8.22 & 16.40 \\
\hline Insurance Services & 0.81 & 4.24 & 2.33 & 4.93 & 5.00 & 6.06 & 17.96 \\
\hline $\begin{array}{l}\text { Computer and Information } \\
\text { Services, of which }\end{array}$ & 0.58 & 3.01 & 1.27 & 2.68 & 2.53 & 3.07 & 14.39 \\
\hline Computer Services & 0.00 & 0.00 & 1.05 & 2.22 & 2.18 & 2.64 & 147.93 \\
\hline Information Services & 0.00 & 0.00 & 0.22 & 0.46 & 0.36 & 0.43 & 159.21 \\
\hline $\begin{array}{l}\text { Personal, Cultural, and } \\
\text { Recreational Services }\end{array}$ & 0.00 & 0.00 & 0.10 & 0.22 & 0.47 & 0.57 & 165.75 \\
\hline Services import total & 19.19 & & 47.29 & 100.00 & 82.54 & & 14.18 \\
\hline
\end{tabular}

(Note) * : Share in total services imports, CAGR : Compound annual growth rate

(Source) Calculated based on IMF (2011) 
Table 5. Services Trade Facilitation Index (STFI)

\begin{tabular}{|c|c|c|c|c|c|c|c|c|c|c|c|c|c|c|}
\hline \multirow{2}{*}{ Country } & \multicolumn{2}{|c|}{2000} & \multicolumn{2}{|c|}{2001} & \multicolumn{2}{|c|}{2002} & \multicolumn{2}{|c|}{2003} & \multicolumn{2}{|c|}{2004} & \multicolumn{2}{|c|}{2005} & \multicolumn{2}{|c|}{2006} \\
\hline & Score & Rank & Score & Rank & Score & Rank & Score & Rank & Score & Rank & Score & Rank & Score & Rank \\
\hline Norway & 2.693 & 1 & 2.797 & 1 & 2.607 & 2 & 2.562 & 2 & 2.540 & 2 & 2.162 & 2 & 3.029 & 1 \\
\hline Luxembourg & 2.014 & 8 & 2.294 & 4 & 2.252 & 4 & 2.253 & 5 & 2.511 & 3 & 1.790 & 1 & 3.001 & 2 \\
\hline Sweden & 2.592 & 2 & 2.615 & 2 & 2.657 & 1 & 2.777 & 1 & 2.722 & 1 & 0.041 & 3 & 2.697 & 3 \\
\hline Denmark & 1.957 & 9 & 2.185 & 5 & 2.473 & 3 & 2.458 & 3 & 2.493 & 4 & 1.809 & 4 & 2.474 & 4 \\
\hline Netherlands & 2.560 & 3 & 2.345 & 3 & 2.096 & 8 & 2.236 & 6 & 2.235 & 5 & 0.610 & 5 & 2.474 & 5 \\
\hline Canada & 2.181 & 5 & 2.033 & 9 & 1.973 & 10 & 2.184 & 7 & 2.172 & 7 & 2.233 & 6 & 2.237 & 6 \\
\hline Japan & 1.416 & 18 & 1.469 & 19 & 1.569 & 18 & 1.568 & 18 & 1.678 & 18 & 0.450 & 18 & 2.144 & 7 \\
\hline Ireland & 1.735 & 14 & 1.882 & 11 & 2.077 & 9 & 2.278 & 4 & 2.199 & 6 & 1.339 & 8 & 2.136 & 8 \\
\hline USA & 2.183 & 4 & 2.114 & 7 & 2.119 & 7 & 2.082 & 9 & 2.105 & 10 & 2.472 & 9 & 2.133 & 9 \\
\hline Finland & 2.053 & 7 & 2.104 & 8 & 2.205 & 6 & 2.172 & 8 & 2.128 & 8 & 2.086 & 11 & 2.110 & 10 \\
\hline HK & 1.819 & 10 & 1.835 & 12 & 1.921 & 12 & 1.971 & 12 & 2.066 & 11 & 1.565 & 10 & 2.082 & 11 \\
\hline Australia & 1.696 & 15 & 1.751 & 14 & 1.972 & 11 & 1.974 & 11 & 2.016 & 12 & 1.775 & 7 & 2.047 & 12 \\
\hline UK & 1.752 & 12 & 1.754 & 13 & 1.839 & 13 & 1.955 & 13 & 1.959 & 13 & 1.200 & 12 & 2.008 & 13 \\
\hline Slovak & 2.176 & 6 & 2.118 & 6 & 2.212 & 5 & 2.081 & 10 & 2.126 & 9 & 2.105 & 13 & 1.850 & 14 \\
\hline Germany & 1.580 & 16 & 1.568 & 17 & 1.581 & 17 & 1.720 & 17 & 1.741 & 16 & 1.124 & 16 & 1.818 & 15 \\
\hline Austria & 1.737 & 13 & 1.685 & 15 & 1.740 & 14 & 1.817 & 14 & 1.777 & 14 & 0.142 & 15 & 1.813 & 16 \\
\hline Belgium & 1.781 & 11 & 1.915 & 10 & 1.678 & 15 & 1.740 & 15 & 1.717 & 17 & 2.148 & 14 & 1.800 & 17 \\
\hline Korea & 1.505 & 17 & 1.578 & 16 & 1.670 & 16 & 1.725 & 16 & 1.760 & 15 & 1.630 & 17 & 1.779 & 18 \\
\hline France & 1.394 & 19 & 1.543 & 18 & 1.512 & 19 & 1.560 & 19 & 1.526 & 20 & 1.705 & 20 & 1.640 & 19 \\
\hline Italy & 1.283 & 20 & 1.355 & 20 & 1.462 & 20 & 1.553 & 20 & 1.590 & 19 & 1.768 & 19 & 1.622 & 20 \\
\hline Czech & 0.906 & 23 & 1.028 & 22 & 1.256 & 21 & 1.272 & 21 & 1.294 & 21 & 3.022 & 21 & 1.415 & 21 \\
\hline Portugal & 1.061 & 21 & 1.102 & 21 & 1.164 & 22 & 1.262 & 22 & 1.232 & 22 & 2.366 & 22 & 1.335 & 22 \\
\hline Greece & 0.977 & 22 & 1.020 & 23 & 1.162 & 23 & 1.151 & 23 & 1.186 & 23 & 2.748 & 23 & 1.237 & 23 \\
\hline Hungary & 0.622 & 24 & 0.778 & 24 & 0.882 & 24 & 1.046 & 24 & 1.084 & 25 & 0.962 & 25 & 1.199 & 24 \\
\hline Singapore & 0.608 & 25 & 0.756 & 25 & 0.845 & 25 & 1.025 & 25 & 1.105 & 24 & 1.284 & 24 & 1.191 & 25 \\
\hline Poland & 0.475 & 26 & 0.536 & 26 & 0.762 & 26 & 0.810 & 26 & 0.875 & 26 & 0.954 & 26 & 1.078 & 26 \\
\hline Russia & 0.366 & 28 & 0.394 & 28 & 0.453 & 28 & 0.575 & 27 & 0.764 & 27 & 1.889 & 27 & 1.076 & 27 \\
\hline South Africa & 0.429 & 27 & 0.446 & 27 & 0.486 & 27 & 0.526 & 28 & 0.568 & 28 & 1.166 & 28 & 0.749 & 28 \\
\hline Brazil & 0.302 & 29 & 0.340 & 29 & 0.403 & 29 & 0.447 & 29 & 0.510 & 29 & 0.729 & 29 & 0.690 & 29 \\
\hline China & 0.164 & 30 & 0.208 & 30 & 0.274 & 30 & 0.339 & 30 & 0.398 & 30 & 0.159 & 30 & 0.500 & 30 \\
\hline Sri Lanka & 0.067 & 31 & 0.076 & 31 & 0.085 & 31 & 0.102 & 31 & 0.123 & 31 & 2.724 & 31 & 0.229 & 31 \\
\hline India & 0.044 & 32 & 0.048 & 32 & 0.064 & 32 & 0.075 & 32 & 0.101 & 32 & 2.005 & 32 & 0.195 & 32 \\
\hline Bangladesh & 0.009 & 33 & 0.011 & 33 & 0.013 & 33 & 0.015 & 33 & 0.020 & 33 & 2.126 & 33 & 0.074 & 33 \\
\hline
\end{tabular}


Table 6. Services Trade Facilitation Indicators: 2006

\begin{tabular}{|c|c|c|c|c|c|c|c|c|c|c|}
\hline \multirow[t]{2}{*}{ Country } & \multicolumn{2}{|c|}{$\begin{array}{l}\text { Internet User } \\
\text { (int_usr) }\end{array}$} & \multicolumn{2}{|c|}{$\begin{array}{l}\text { International } \\
\text { Internet } \\
\text { Bandwidth } \\
\text { (int_bw) }\end{array}$} & \multicolumn{2}{|c|}{$\begin{array}{c}\text { Per Capita } \\
\text { Consumption of } \\
\text { Electricity } \\
\text { (pce) }\end{array}$} & \multicolumn{2}{|c|}{$\begin{array}{c}\text { Air Transport } \\
\text { Passengers } \\
\text { Carried } \\
\text { (air_p) }\end{array}$} & \multicolumn{2}{|c|}{$\begin{array}{l}\text { Fixed Line and } \\
\text { Mobile Phone } \\
\text { Subscribers } \\
\text { (tel) }\end{array}$} \\
\hline & Score & Rank & Score & Rank & Score & Rank & Score & Rank & Score & Rank \\
\hline Australia & 0.746 & 4 & 0.000 & 32 & 0.471 & 7 & 0.117 & 6 & 0.713 & 17 \\
\hline Austria & 0.512 & 14 & 0.150 & 13 & 0.327 & 11 & 0.055 & 14 & 0.770 & 11 \\
\hline Bangladesh & 0.003 & 33 & 0.000 & 33 & 0.006 & 33 & 0.001 & 33 & 0.065 & 33 \\
\hline Belgium & 0.477 & 17 & 0.279 & 6 & 0.349 & 8 & 0.018 & 22 & 0.678 & 20 \\
\hline Brazil & 0.227 & 26 & 0.004 & 26 & 0.083 & 29 & 0.011 & 25 & 0.364 & 29 \\
\hline Canada & 0.709 & 7 & 0.154 & 12 & 0.709 & 2 & 0.074 & 11 & 0.591 & 25 \\
\hline China & 0.105 & 29 & 0.001 & 27 & 0.073 & 30 & 0.006 & 29 & 0.314 & 30 \\
\hline Czech & 0.348 & 22 & 0.049 & 19 & 0.260 & 17 & 0.025 & 21 & 0.733 & 15 \\
\hline Denmark & 0.589 & 10 & 0.789 & 1 & 0.273 & 16 & 0.006 & 30 & 0.817 & 7 \\
\hline Finland & 0.561 & 11 & 0.098 & 15 & 0.660 & 3 & 0.074 & 10 & 0.716 & 16 \\
\hline France & 0.496 & 15 & 0.075 & 17 & 0.325 & 12 & 0.050 & 15 & 0.694 & 18 \\
\hline Germany & 0.473 & 18 & 0.155 & 11 & 0.292 & 14 & 0.062 & 13 & 0.836 & 5 \\
\hline Greece & 0.185 & 27 & 0.022 & 22 & 0.215 & 23 & 0.044 & 17 & 0.771 & 10 \\
\hline $\mathrm{HK}$ & 0.555 & 13 & 0.164 & 9 & 0.241 & 20 & 0.164 & 3 & 0.957 & 2 \\
\hline Hungary & 0.351 & 21 & 0.022 & 23 & 0.155 & 27 & 0.013 & 24 & 0.658 & 22 \\
\hline India & 0.079 & 31 & 0.001 & 30 & 0.021 & 31 & 0.002 & 32 & 0.093 & 32 \\
\hline Ireland & 0.340 & 23 & 0.137 & 14 & 0.256 & 19 & 0.613 & 1 & 0.791 & 8 \\
\hline Italy & 0.495 & 16 & 0.023 & 21 & 0.232 & 22 & 0.032 & 20 & 0.839 & 4 \\
\hline Japan & 0.691 & 9 & 0.463 & 4 & 0.338 & 10 & 0.042 & 18 & 0.610 & 24 \\
\hline Korea & 0.711 & 6 & 0.023 & 20 & 0.319 & 13 & 0.037 & 19 & 0.689 & 19 \\
\hline Luxembourg & 0.741 & 5 & 0.468 & 2 & 0.654 & 4 & 0.104 & 7 & 1.034 & 1 \\
\hline Netherlands & 0.898 & 1 & 0.464 & 3 & 0.286 & 15 & 0.087 & 8 & 0.739 & 13 \\
\hline Norway & 0.882 & 2 & 0.211 & 8 & 1.030 & 1 & 0.150 & 4 & 0.757 & 12 \\
\hline Poland & 0.291 & 25 & 0.013 & 25 & 0.141 & 28 & 0.005 & 31 & 0.629 & 23 \\
\hline Portugal & 0.306 & 24 & 0.019 & 24 & 0.191 & 26 & 0.046 & 16 & 0.773 & 9 \\
\hline Russia & 0.182 & 28 & 0.066 & 18 & 0.237 & 21 & 0.010 & 26 & 0.581 & 26 \\
\hline Slovak & 0.386 & 20 & 0.160 & 10 & 0.342 & 9 & 0.225 & 2 & 0.736 & 14 \\
\hline Singapore & 0.422 & 19 & 0.001 & 29 & 0.202 & 24 & 0.007 & 28 & 0.559 & 27 \\
\hline South Africa & 0.095 & 30 & 0.000 & 31 & 0.199 & 25 & 0.014 & 23 & 0.440 & 28 \\
\hline Sri Lanka & 0.022 & 32 & 0.001 & 28 & 0.016 & 32 & 0.008 & 27 & 0.182 & 31 \\
\hline Sweden & 0.776 & 3 & 0.395 & 5 & 0.633 & 5 & 0.073 & 12 & 0.821 & 6 \\
\hline UK & 0.559 & 12 & 0.262 & 7 & 0.256 & 18 & 0.083 & 9 & 0.848 & 3 \\
\hline USA & 0.701 & 8 & 0.075 & 16 & 0.559 & 6 & 0.125 & 5 & 0.673 & 21 \\
\hline
\end{tabular}


Table 7. Initial Augmented Gravity Model Estimations

Dependent variable: bilateral exports (in log scale)

\begin{tabular}{|c|c|c|c|c|c|c|}
\hline Variable & 1 & 2 & 3 & 4 & 5 & 6 \\
\hline \multirow{2}{*}{ GDP of reporter } & $1.650 * * *$ & $1.433 * * *$ & & $1.558 * * *$ & 0.407 & 2.561 \\
\hline & $(0.473)$ & $(0.46)$ & & $(0.484)$ & $(0.759)$ & $(2.427)$ \\
\hline \multirow{2}{*}{ GDP of partner } & $0.716^{* *}$ & $0.962 * * *$ & & $0.783 * * *$ & $0.769 * * *$ & $0.766 * * *$ \\
\hline & $(0.282)$ & $(0.268)$ & & $(0.154)$ & $(0.152)$ & $(0.150)$ \\
\hline \multirow{2}{*}{$\begin{array}{l}\text { GDP per capita } \\
\text { of reporter }\end{array}$} & & & $2.253 * * *$ & & & \\
\hline & & & $(0.572)$ & & & \\
\hline \multirow{2}{*}{$\begin{array}{l}\text { GDP per capita } \\
\text { of partner }\end{array}$} & & & 0.241 & & & \\
\hline & & & $(0.313)$ & & & \\
\hline \multirow{2}{*}{$\begin{array}{l}\text { Distance between } \\
\text { reporter and partner }\end{array}$} & & $-1.778 * * *$ & 0.466 & $-0.938 * *$ & $-0.961 * *$ & $-0.894 * *$ \\
\hline & & $(0.583)$ & $(0.582)$ & $(0.371)$ & $(0.389)$ & $(0.352)$ \\
\hline \multirow{2}{*}{ RTA dummy+ } & & & 0.213 & 0.27 & 0.243 & 0.356 \\
\hline & & & $(0.750)$ & (1.131) & (1.127) & (1.139) \\
\hline \multirow{2}{*}{$\begin{array}{l}\text { Landlocked } \\
\text { dummy+ }\end{array}$} & & & $-3.243 * *$ & $-2.426^{* *}$ & $-2.440 * *$ & $-2.445^{* *}$ \\
\hline & & & (1.229) & $(1.085)$ & $(1.085)$ & $(1.072)$ \\
\hline \multirow{2}{*}{$\begin{array}{l}\text { Language } \\
\text { dummy+ }\end{array}$} & & & $1.342 *$ & $1.577 * * *$ & $1.588 * * *$ & $1.630 * * *$ \\
\hline & & & $(0.657)$ & $(0.434)$ & $(0.437)$ & $(0.452)$ \\
\hline \multirow{2}{*}{$\begin{array}{l}\text { Border (adjacency) } \\
\text { dummy+ }\end{array}$} & & & 2.062 & 0.752 & 0.999 & 1.334 \\
\hline & & & $(1.475)$ & $(1.244)$ & $(1.312)$ & (1.316) \\
\hline \multirow{2}{*}{$\begin{array}{l}\text { Internet users } \\
\text { of reporter }\end{array}$} & & & & & 0.298 & \\
\hline & & & & & $(0.310)$ & \\
\hline \multirow{2}{*}{$\begin{array}{l}\text { Internet users } \\
\text { of partner }\end{array}$} & & & & & 0.0781 & \\
\hline & & & & & $(0.248)$ & \\
\hline \multirow{2}{*}{$\begin{array}{l}\text { International internet } \\
\text { bandwidth of reporter }\end{array}$} & & & & & & -0.263 \\
\hline & & & & & & $(0.548)$ \\
\hline \multirow{2}{*}{$\begin{array}{l}\text { International internet } \\
\text { bandwidth of partner }\end{array}$} & & & & & & 0.107 \\
\hline & & & & & & $(0.107)$ \\
\hline Observations & 224 & 224 & 224 & 224 & 224 & 224 \\
\hline R-squared & 0.207 & 0.273 & 0.395 & 0.524 & 0.525 & 0.529 \\
\hline Year effect & Yes & Yes & Yes & Yes & Yes & Yes \\
\hline Country effect & Yes & Yes & Yes & Yes & Yes & Yes \\
\hline
\end{tabular}


Table 7. Initial Augmented Gravity Model Estimations (continued)

Dependent variable: bilateral exports (in log scale)

\begin{tabular}{|c|c|c|c|c|c|c|}
\hline Variable & 7 & 8 & 9 & 10 & 11 & 12 \\
\hline \multirow{2}{*}{ GDP of reporter } & $6.905^{*}$ & 1.298 & -4.397 & $9.344 *$ & $1.545^{* *}$ & $1.626^{* *}$ \\
\hline & $(4.034)$ & $(1.557)$ & $(3.627)$ & $(5.200)$ & $(0.598)$ & $(0.635)$ \\
\hline \multirow{2}{*}{ GDP of partner } & $0.783 * * *$ & $1.780 * * *$ & $0.783^{* * * *}$ & $0.716^{* * * *}$ & $0.817^{* * * *}$ & $0.731 * * *$ \\
\hline & $(0.152)$ & $(0.264)$ & $(0.155)$ & $(0.154)$ & $(0.149)$ & $(0.157)$ \\
\hline \multirow{2}{*}{$\begin{array}{l}\text { Distance between } \\
\text { reporter and partner }\end{array}$} & $-0.939 * *$ & -0.397 & $-0.946 * *$ & $-0.913 * *$ & $-1.175^{* *}$ & $-0.995 * *$ \\
\hline & $(0.388)$ & $(0.415)$ & $(0.379)$ & $(0.423)$ & $(0.446)$ & $(0.418)$ \\
\hline \multirow{2}{*}{ RTA dummy +} & 0.27 & -0.143 & 0.255 & 0.386 & 0.332 & 0.294 \\
\hline & $(1.159)$ & $(0.787)$ & (1.136) & $(1.051)$ & (1.115) & (1.063) \\
\hline \multirow{2}{*}{ Landlocked dummy +} & $-2.425 * *$ & $-1.967 * *$ & $-2.426 * *$ & $-2.222 * *$ & $-2.429 * *$ & $-2.318 * *$ \\
\hline & (1.102) & $(0.844)$ & (1.089) & $(0.969)$ & $(1.061)$ & $(1.027)$ \\
\hline \multirow{2}{*}{ Language dummy +} & $1.578^{* * * *}$ & $2.077 * * *$ & $1.585^{* * *}$ & 1.431 *** & $1.526^{* * *}$ & $1.503^{* * *}$ \\
\hline & $(0.435)$ & $(0.335)$ & $(0.446)$ & $(0.494)$ & $(0.455)$ & $(0.455)$ \\
\hline \multirow{2}{*}{$\begin{array}{l}\text { Border (adjacency) } \\
\text { dummy }+\end{array}$} & 0.762 & $1.858 * *$ & 0.797 & $2.529 * *$ & 1.48 & 1.683 \\
\hline & $(1.232)$ & $(0.855)$ & $(1.204)$ & $(1.16)$ & $(1.067)$ & $(1.032)$ \\
\hline \multirow{2}{*}{$\begin{array}{l}\text { Per capita consumption } \\
\text { of electricity of reporter }\end{array}$} & -16.71 & & & & & \\
\hline & $(11.54)$ & & & & & \\
\hline \multirow{2}{*}{$\begin{array}{l}\text { Per capita consumption } \\
\text { of electricity of partner }\end{array}$} & 0.00379 & & & & & \\
\hline & $(0.239)$ & & & & & \\
\hline \multirow{2}{*}{$\begin{array}{l}\text { Air transport passengers } \\
\text { carried of reporter }\end{array}$} & & 0.138 & & & & \\
\hline & & $(0.977)$ & & & & \\
\hline \multirow{2}{*}{$\begin{array}{l}\text { Air transport passengers } \\
\text { carried of partner }\end{array}$} & & $1.015 * * *$ & & & & \\
\hline & & $(0.243)$ & & & & \\
\hline \multirow{2}{*}{$\begin{array}{l}\text { Fixed line and mobile phone } \\
\text { subscribers of reporter }\end{array}$} & & & 2.698 & & & \\
\hline & & & (1.715) & & & \\
\hline \multirow{2}{*}{$\begin{array}{l}\text { Fixed line and mobile phone } \\
\text { subscribers of partner }\end{array}$} & & & 0.0183 & & & \\
\hline & & & $(0.246)$ & & & \\
\hline \multirow{2}{*}{$\begin{array}{l}\text { ICT expenditure } \\
\text { of reporter }\end{array}$} & & & & -4.81 & & \\
\hline & & & & $(3.025)$ & & \\
\hline \multirow{2}{*}{$\begin{array}{l}\text { ICT expenditure } \\
\text { of partner }\end{array}$} & & & & $0.507 *$ & & \\
\hline & & & & $(0.258)$ & & \\
\hline \multirow{2}{*}{$\begin{array}{l}\text { Regulatory quality } \\
\text { of reporter }\end{array}$} & & & & & -0.661 & \\
\hline & & & & & $(1.506)$ & \\
\hline \multirow{2}{*}{$\begin{array}{l}\text { Regulatory quality } \\
\text { of partner }\end{array}$} & & & & & $0.626^{*}$ & \\
\hline & & & & & $(0.308)$ & \\
\hline \multirow{2}{*}{$\begin{array}{l}\text { Global competitiveness } \\
\text { of reporter }\end{array}$} & & & & & & -0.794 \\
\hline & & & & & & $(2.92)$ \\
\hline \multirow{2}{*}{$\begin{array}{l}\text { Global competitiveness } \\
\text { of partner }\end{array}$} & & & & & & $3.169^{*}$ \\
\hline & & & & & & (1.604) \\
\hline
\end{tabular}




\begin{tabular}{|l|c|c|c|c|c|c|}
\hline Observations & 224 & 224 & 224 & 224 & 224 & 224 \\
\hline R-squared & 0.525 & 0.595 & 0.528 & 0.552 & 0.535 & 0.543 \\
\hline Year effect & Yes & Yes & Yes & Yes & Yes & Yes \\
\hline Country effect & Yes & Yes & Yes & Yes & Yes & Yes \\
\hline
\end{tabular}

(Note) $* * *, * *, *$ significant at $1 \%, 5 \%$, and 10\% level. Robust standard errors are in parentheses. Constant terms are not shown. Abbreviated terms of variables refer Appendix 4. All the variables are taken in natural log except those are indicated. + : not in log scale

\section{Table 8. Three-stage Augmented Gravity Estimations}

Dependent variable for the first and the third stages : bilateral exports (in log scale)

Dependent variable for the second stage : the first-stage residuals

\begin{tabular}{|c|c|c|c|c|c|}
\hline Variable & First stage & Second stage & Third Stage (I) & Third Stage (II) & Third Stage (III) \\
\hline \multirow{2}{*}{ GDP of reporter } & 1.657 & & 1.667 & 2.862 & -0.371 \\
\hline & $(1.154)$ & & $(1.168)$ & (3.246) & $(1.428)$ \\
\hline \multirow{2}{*}{ GDP of partner } & $0.683 * * *$ & & $0.682 * * *$ & $0.707 * * *$ & $0.686^{* * *}$ \\
\hline & $(0.13)$ & & $(0.129)$ & $(0.125)$ & $(0.127)$ \\
\hline \multirow{2}{*}{$\begin{array}{l}\text { Control of corruption } \\
\text { of reporter }\end{array}$} & 0.286 & & 0.276 & 0.543 & 6.931 \\
\hline & (2.727) & & $(2.736)$ & (2.186) & (5.011) \\
\hline \multirow{2}{*}{$\begin{array}{l}\text { Control of corruption } \\
\text { of partner }\end{array}$} & 0.486 & & 0.484 & $0.923 *$ & 0.644 \\
\hline & $(0.468)$ & & $(0.468)$ & $(0.483)$ & $(0.442)$ \\
\hline \multirow{2}{*}{$\begin{array}{l}\text { Exchange rate } \\
\text { of reporter }\end{array}$} & 5.642 & & 5.656 & 6.972 & -0.725 \\
\hline & $(4.097)$ & & (4.117) & $(5.644)$ & (2.145) \\
\hline \multirow{2}{*}{$\begin{array}{l}\text { Exchange rate } \\
\text { of partner }\end{array}$} & $-0.258^{*}$ & & $-0.255^{*}$ & $-0.293 * *$ & $-0.278^{*}$ \\
\hline & $(0.141)$ & & $(0.144)$ & $(0.138)$ & $(0.148)$ \\
\hline \multirow{2}{*}{$\begin{array}{l}\text { Border (adjacency) } \\
\text { dummy }+\end{array}$} & $1.871^{* *}$ & & $1.836^{*}$ & 0.941 & 1.582 \\
\hline & $(0.913)$ & & $(0.901)$ & (1.205) & (1.116) \\
\hline \multirow{2}{*}{ Language dummy+ } & $1.379 * *$ & & $1.381 * *$ & $1.294 * *$ & $1.386^{* *}$ \\
\hline & $(0.56)$ & & $(0.564)$ & $(0.549)$ & $(0.555)$ \\
\hline \multirow{2}{*}{ Landlocked dummy+ } & $-1.746^{*}$ & & $-1.774 *$ & $-1.587^{*}$ & $-1.692 *$ \\
\hline & $(0.931)$ & & $(0.972)$ & $(0.829)$ & $(0.882)$ \\
\hline \multirow{2}{*}{ RTA dummy +} & 1.447 & & 1.45 & 1.499 & 1.461 \\
\hline & $(1.035)$ & & (1.046) & $(0.998)$ & (1.024) \\
\hline \multirow{2}{*}{$\begin{array}{l}\text { Distance between } \\
\text { reporter and partner }\end{array}$} & & -0.595 & & & \\
\hline & & $(0.657)$ & & & \\
\hline \multirow{2}{*}{$\begin{array}{l}\text { Air transport passengers } \\
\text { carried of reporter }\end{array}$} & & $-3.685^{* * *}$ & & & \\
\hline & & (1.132) & & & \\
\hline \multirow{2}{*}{$\begin{array}{l}\text { Air transport passengers } \\
\text { carried of partner }\end{array}$} & & $0.619 * * *$ & & & \\
\hline & & $(0.223)$ & & & \\
\hline \multirow{2}{*}{$\begin{array}{l}\text { ICT expenditure } \\
\text { of reporter }\end{array}$} & & $3.090 * * *$ & & & \\
\hline & & $(0.672)$ & & & \\
\hline
\end{tabular}




\begin{tabular}{|c|c|c|c|c|c|}
\hline \multirow{2}{*}{$\begin{array}{l}\text { ICT expenditure } \\
\text { of partner }\end{array}$} & & 0.119 & & & \\
\hline & & $(0.499)$ & & & \\
\hline \multirow{2}{*}{$\begin{array}{l}\text { Regulatory quality } \\
\text { of reporter }\end{array}$} & & $-1.333 * * *$ & & & \\
\hline & & $(0.446)$ & & & \\
\hline \multirow{2}{*}{$\begin{array}{l}\text { Regulatory quality } \\
\text { of partner }\end{array}$} & & -1.114 & & & \\
\hline & & $(1.086)$ & & & \\
\hline \multirow{2}{*}{$\begin{array}{l}\text { Global competitiveness } \\
\text { of reporter }\end{array}$} & & $14.23 * * *$ & & & \\
\hline & & $(3.496)$ & & & \\
\hline \multirow{2}{*}{$\begin{array}{l}\text { Global competitiveness } \\
\text { of partner }\end{array}$} & & 2.926 & & & \\
\hline & & $(2.572)$ & & & \\
\hline \multirow{2}{*}{ STFI (1) of reporter } & & & 0.0621 & & \\
\hline & & & $(0.327)$ & & \\
\hline \multirow{2}{*}{ STFI (1) of partner } & & & 0.0171 & & \\
\hline & & & $(0.135)$ & & \\
\hline \multirow{2}{*}{ STFI (2) of reporter } & & & & 0.508 & \\
\hline & & & & $(1.101)$ & \\
\hline \multirow{2}{*}{ STFI (2) of partner } & & & & 0.527 & \\
\hline & & & & $(0.354)$ & \\
\hline \multirow[b]{2}{*}{ STFI (3) of reporter } & & & & & 1.504 \\
\hline & & & & & $(0.99)$ \\
\hline \multirow[b]{2}{*}{ STFI (3) of partner } & & & & & 0.486 \\
\hline & & & & & $(0.733)$ \\
\hline Observations & 224 & 224 & 224 & 224 & 224 \\
\hline R-squared & 0.514 & 0.418 & 0.545 & 0.554 & 0.549 \\
\hline
\end{tabular}

(Note) $* * *, * *, *$ significant at $1 \%, 5 \%$, and 10\% level. Robust standard errors are in parentheses. Constant terms are not shown. Abbreviated terms of variables refer Appendix 4. All the variables are taken in natural log except those are indicated. + : not in log scale 
Table 9. HTM Estimates

Dependent variable: bilateral exports (in log scale)

\begin{tabular}{|c|c|c|c|c|c|}
\hline Variable & 1 & 2 & 3 & 4 & 5 \\
\hline \multirow{2}{*}{$\begin{array}{l}\text { Control of corruption } \\
\text { of reporter }\end{array}$} & 0.616 & 0.726 & 8.72 & 1.075 & 8.688 \\
\hline & $(2.558)$ & (2.538) & (6.994) & $(2.869)$ & (7.06) \\
\hline \multirow{2}{*}{$\begin{array}{l}\text { Control of corruption } \\
\text { of partner }\end{array}$} & -0.763 & -0.72 & -0.582 & -0.59 & -0.628 \\
\hline & $(0.771)$ & $(0.761)$ & $(0.782)$ & $(0.869)$ & $(0.79)$ \\
\hline \multirow{2}{*}{ GDP of reporter } & 0.0309 & 0.0696 & 2.621 & 1.354 & 2.578 \\
\hline & $(1.052)$ & $(1.061)$ & $(2.38)$ & $(4.87)$ & (2.396) \\
\hline \multirow{2}{*}{ GDP of partner } & $3.604 * * *$ & $3.530 * * *$ & $4.069 * * *$ & $3.406^{* * *}$ & $4.203 * * *$ \\
\hline & $(1.027)$ & $(0.989)$ & $(1.156)$ & $(1.120$ & (1.203) \\
\hline \multirow{2}{*}{ Exchange rate of reporter } & 6.129 & $6.519^{*}$ & 0.258 & 7.501 & 0.000182 \\
\hline & $(3.864)$ & (3.838) & $(7.671)$ & $(5.937)$ & (7.745) \\
\hline \multirow{2}{*}{ Exchange rate of partner } & 1.207 & 0.781 & 1.058 & 0.939 & 1.455 \\
\hline & $(0.888)$ & $(0.89)$ & $(0.978)$ & (1.058) & $(0.979)$ \\
\hline \multirow{2}{*}{$\begin{array}{l}\text { Distance between reporter } \\
\text { and partner }\end{array}$} & & $-1.055^{*}$ & $-1.276^{*}$ & $-1.361^{*}$ & \\
\hline & & $(3.255)$ & $(3.786)$ & $(3.489)$ & \\
\hline \multirow{2}{*}{ RTA dummy+ } & -0.878 & -0.852 & -1.046 & -1.017 & -1.075 \\
\hline & $(0.783)$ & $(0.775)$ & $(0.775)$ & $(0.781)$ & $(0.784)$ \\
\hline \multirow{2}{*}{ Border (adjacency) dummy +} & 2.002 & -2.214 & -4.23 & -1.827 & 0.196 \\
\hline & $(3.642)$ & $(4.06)$ & $(5.365)$ & $(4.87)$ & $(4.583)$ \\
\hline \multirow{2}{*}{ Language dummy +} & 2.113 & 2.489 & 2.536 & 2.315 & 2.187 \\
\hline & $(1.971)$ & $(1.869)$ & (2.244) & $(2.063)$ & (2.329) \\
\hline \multirow{2}{*}{ Landlocked dummy+ } & -1.292 & -1.163 & -0.995 & -1.408 & -0.955 \\
\hline & $(3.234)$ & $(3.057)$ & $(3.576)$ & $(3.317)$ & $(3.742)$ \\
\hline \multirow{2}{*}{ STFI (1) of reporter } & $1.957^{*}$ & $1.855^{*}$ & & & \\
\hline & $(0.364)$ & $(0.36)$ & & & \\
\hline \multirow{2}{*}{ STFI (1) of partner } & 0.118 & 0.122 & & & \\
\hline & $(0.0909)$ & $(0.0902)$ & & & \\
\hline \multirow{2}{*}{ STFI (2) of reporter } & & & 1.343 & & 1.316 \\
\hline & & & $(1.611)$ & & $(1.627)$ \\
\hline \multirow{2}{*}{ STFI (2) of partner } & & & 2.186 & & 2.334 \\
\hline & & & $(1.94)$ & & $(1.98)$ \\
\hline \multirow{2}{*}{ STFI (3) of reporter } & & & & 1.634 & \\
\hline & & & & $(2.373)$ & \\
\hline \multirow{2}{*}{ STFI (3) of partner } & & & & 1.0898 & \\
\hline & & & & $(0.757)$ & \\
\hline Observations & 224 & 224 & 224 & 224 & 224 \\
\hline Number of reporters & 32 & 32 & 32 & 32 & 32 \\
\hline Wald $\chi^{2}$ ( $p$-value) & $59.31(0.00)$ & $61.03(0.00)$ & $56.90(0.00)$ & $55.63(0.00)$ & $55.64(0.00)$ \\
\hline
\end{tabular}

(Note) $* * *, * *, *$ significant at $1 \%, 5 \%$, and $10 \%$ level. Robust standard errors are in parentheses. Constant terms are not shown. Abbreviated terms of variables refer Appendix 4. All the variables are taken in natural log except those are indicated. + : not in log scale. 


\section{References}

Amemiya, T. and T. E. MaCurdy. 1986. "Instrumental Variable Estimation of an Error Component Model". Econometrica Vol. 54, pp. 869-880

Anderson, J. E. 1979. "A Theoretical Foundation for the Gravity Equation”. American Economic Review, Vol. 69, pp. 106-116.

Anderson, J. E., and E. van Wincoop. 2003. "Gravity with Gravitas: A Solution to the Border Puzzle". American Economic Review, Vol. 93, No. 1, pp. 170-192

Anderson, J. E. and E. van Wincoop. 2004. "Trade Costs”. Journal of Economic Literature. Vol. XLII, No. 3, pp. $691-751$.

Bhagwati, J. N. 1987 "Trade in Services and the Multilateral Trade Negotiations". World Bank Economic Review, Vol. 1(4), pp. 549-69.

Brown, Drusilla K. and Stern, Robert M. 2001. "Measurement and Modeling of the Economic Effects of Trade and Investment Barriers in Services”. Review of International Economics Vol. 9, pp. 262- 286.

Brown, D., A. Deardorff and R. Stern. 2002. Computational Analysis of Goods and Services Liberalization in the Uruguay Round and the Doha Development Round. Discussion Paper No. 489. Research Seminar in International Economics, School of Public Policy, The University of Michigan.

Chanda, Rupa. 2006. (ed.) Trade in Services and India: Prospects and Strategies. New Delhi: Wiley-India.

Cheng, I.-H, and H. Wall. 2005. "Controlling for Heterogeneity in Gravity Models of Trade and Integration”. Federal Reserve Bank of St. Louis Review, Vol. 87, pp. 49-63.

Copeland, B. and A. Mattoo. 2008. "The Basic Economics of Services Trade" in Mattoo et al. (2008).

De Groot, H. L. F., et al. 2004. "The Institutional Determinants of Bilateral Trade Flows”. Kyklos Vol. 57, No. 1, pp. 103-123.

Deardroff, A. 2001. "International Provision of Trade Services, Trade and Fragmentation”. Review of International Economics, Vol. 9, No. 2, pp. 233-248

Deardorff, A. V. and R. M. Stern. 2008 "Empirical Analysis of Barriers to International Services Transactions and the Consequences of Liberalisation" in Mattoo et al. (2008).

Egger, P. 2002 "An Econometric View of the Estimation of Gravity Models and the Calculation of Trade Potentials.” The World Economy, Vol. 25, No. 2, pp. 297-312.

Egger, P. 2005. "Alternative Techniques for Estimation of Cross-Section Gravity Models". Review of International Economics, Vol. 13, pp. 881-891

Egger, P and M. Pfaffermayr. 2004 "Distance, Trade and FDI: A Hausman-Taylor SUR Approach". Journal of Applied Econometrics. Vol. 19, pp. 227-246.

Egger, P. and D. Nelson. 2006. "The Effect of Antidumping on Bilateral Trade in the Multilateral Trading System: Evidence from Panel Data”. Paper presented at the Annual Conference on the European Trade Study Group, September 2006.

Findlay, C. and T. Warren. 2000. Impediments to Trade in Services: Measurement and Policy Implication. New York: Routledge. 
Francois, J., Hans van Meijl, and Frank van Tongeren. 2003. "Economic Implications of Trade Liberalization Under the Doha Round," Working Papers 2003-20, CEPII Research Center, Paris.

Francois, J., O. Pindyuk and J. Woerz. 2009. "Trends in International Trade and FDI in Services: A Global Database of Services Trade," IIDE Discussion Papers 20090802, Institute for International and Development Economics, Linz.

Francois, J. and B. Hoekman. 2010. "Services Trade and Policy". Journal of Economic Literature, Vol. 48 (September 2010), pp. $642-692$.

Francois, J. 1999. Estimates of Barriers to Trade in Services, Erasmus University, Unpublished manuscript.

Francois, J. 2001. "Trade Policy Transparency and Investor Confidence: Some Implications for an Effective Trade Policy Review Mechanism”, Review of International Economics, vol. 9, No. 2, pp. 303-16

Gene M. Grossman and Rossi-Hansberg. Esteban, 2008a. External Economies and International Trade Redux, NBER Working Papers 14425, National Bureau of Economic Research, Inc.

Grossman, Gene M., and Rossi-Hansberg. Esteban. 2008b. "Trading Tasks: A Simple Theory of Offshoring." American Economic Review, Vol. 98, No. 5, pp. 1978-97.

Ghani, E. and H. Kharas. 2010. "The Services Revolution in South Asia" in Ghani E. (ed.) The Services Revolution in South Asia. New Delhi: Oxford University Press (OUP).

Government of India. 2010. Economic Survey 2009-10, Ministry of Finance, New Delhi

Grunfeld, L. and A. Moxnes. 2003. "The Intangible Globalisation: Explaining Patterns of International Trade in Services". Norwegian Institute of International Affairs Paper \# 657, Oslo.

Hausman, J. and W. Taylor. 1981. "Panel Data and Unobservable Effects". Econometrica, Vol. 49, pp. 13771398.

Hoekman, B. 2000. The Next Round of Services Negotiations: Identifying Priorities and Options. Multilateral Trade Negotiations: Issues for the Millennium Round. Federal Reserve Bank of St. Louis, St. Louis.

IMF. 2011. Balance of Payments Statistics Yearbook Online Database. International Monetary Fund, Washington, D.C.

Jacks, D. S., Christopher, M. M. and D. Novy. 2008. "Trade Costs: 1870-2000". American Economic Review, Vol. 98 , No. 2 pp. $529-534$

Kimura, F. and H.-H. Lee. 2006. "The Gravity Equation in International Trade in Services". Review of World Economics, Vol. 142, pp. 92-121.

Konan, D. E. and K. E. Maskus. 2006. "Quantifying the Impact of Services Liberalization in a Developing Country" Journal of Development Economics, Vol. 81, pp. 142- 162

Lejour, A. and J.-W. de Paiva Verheijden. 2004. "Services Trade within Canada and the European Union : What do They Have in Common?" CPB Discussion Paper \# 42.

Linnemann, H. 1966. An Econometric Study of International Trade Flows, North Holland Publishing, Amsterdam.

Marchetti, A and M. Roy. 2008. Opening Markets for Trade in Services: Countries and Sectors in Bilateral and WTO Negotiations, Cambridge: Cambridge University Press (CUP).

Mattoo, A., R. M. Stern, and G. Zanini (eds.) 2008. A Handbook of International Trade in Services. Oxford: 
Oxford University Press (OUP).

Mishra S., S. Lundstrom, and R. Anand. 2011. Service Export Sophistication and Economic Growth. Policy Research Working Paper 5606, The World Bank, Washington, D. C.

Moreira, M. M., C. Volpe and J. S. Blyde, 2008. Unclogging the Arteries: The Impact of Transport Costs on Latin American and Caribbean Trade. Inter-American Development Bank, Washington, D. C.

Nordås, H. K. and R. Piermartini. 2004. "Infrastructure and Trade", Staff Working Paper ERSD-2004-04, World Trade Organization (WTO), Geneva.

Organization for Economic Cooperation and Development (OECD). 2003. Statistics on International Trade in Services, OECD, Paris.

Park, S-C. 2002. "Measuring Tariff Equivalents in Cross-Border Trade in Services". Korea Institute for International Economic Policy, Working Paper \# 02-15, Seoul.

Portes, R. and H. Rey. 2005. "The Determinants of Cross-border Equity Flows", Journal of International Economics, vol. 65, pp. 269-296

Poyhonen, P., 1963. "A Tentative Model for the Volume of Trade between Countries". Weltwirtschaftliches Archiv, vol. 90, No. 1, pp. 93-99.

Reserve Bank of India. 2011. Database on Indian Economy. Reserve Bank of India (RBI), Mumbai.

Rodrik, D., A. Subramanian, and F. Trebbi. 2002. Institutions Rule: The Primacy of Institutions over Geography and Integration in Economic Development. NBER Working Paper 9305. Cambridge: NBER.

Shepherd, B. 2012. The Gravity Model of International Trade: A User Guide, United Nations Economic and Social Commission for India and the Pacific (UNESCAP), Bangkok.

Stern, Robert M. 2002. "Quantifying Barriers to Trade in Services". in Hoekman, Bernard; Mattoo, Aaditya and English, Philip (eds.) Development, Trade and the WTO: A Handbook. World Bank, Washington DC.

Tharakan, P., I. van Beveren and T. van Outri. 2005. "The Determinants of India's Software Exports and Goods Exports”. Review of Economics and Statistics, Vol. 87, pp. 776-780.

Tinbergen, Jan. 1962. Shaping the World Economy: Suggestions for an International Economic Policy. New York: The Twentieth Century Fund.

Warren, Tony, and Christopher Findlay. 2000. "Measuring Impediments to Trade in Services." in Sauvé P and Robert M. Stern (eds.) GATS 2000: New Directions in Services Trade Liberalization, pp. 57-84. Cambridge: Harvard University Center for Business and Government; Washington, D.C.: Brookings Institution Press.

World Bank. 2010. World Development Indicators CD-ROM 2010 Washington, D.C.

World Trade Organization (WTO). 2012. A Practical Guide to Trade Policy Analysis, WTO, Geneva. 


\section{Appendices}

\section{Appendix 1. PCA Weights $(W)$}

\begin{tabular}{|l|c|c|c|c|c|c|c|c|}
\hline \multirow{2}{*}{ Components } & \multicolumn{2}{|c|}{2000} & \multicolumn{2}{c|}{2001} & \multicolumn{2}{c|}{2002} & \multicolumn{2}{c|}{2003} \\
\cline { 2 - 9 } & $W$ & Rank & $W$ & Rank & $W$ & Rank & $W$ & Rank \\
\hline Internet users & 0.228 & 1 & 0.226 & 1 & 0.233 & 1 & 0.234 & 1 \\
\hline $\begin{array}{l}\text { Internet } \\
\text { bandwidth }\end{array}$ & 0.159 & 5 & 0.160 & 5 & 0.155 & 5 & 0.174 & 4 \\
\hline $\begin{array}{l}\text { Electric power } \\
\text { consumption }\end{array}$ & 0.199 & 3 & 0.203 & 3 & 0.204 & 3 & 0.204 & 3 \\
\hline $\begin{array}{l}\text { Air passengers } \\
\text { Telephone }\end{array}$ & 0.188 & 4 & 0.186 & 4 & 0.177 & 4 & 0.156 & 5 \\
\hline $\begin{array}{l}\text { Eigenvalue } \\
\text { component 1) }\end{array}$ & 3.226 & 2 & 0.224 & 2 & 0.231 & 2 & 0.232 & 2 \\
\hline $\begin{array}{l}\text { Proportion } \\
\text { explained (\%) }\end{array}$ & 64.520 & 3.177 & & 3.000 & & 2.976 & \\
\hline
\end{tabular}

\begin{tabular}{|l|c|c|c|c|c|c|}
\hline \multirow{2}{*}{ Components } & \multicolumn{2}{|c|}{2004} & \multicolumn{2}{c|}{2005} & \multicolumn{2}{c|}{2006} \\
\cline { 2 - 7 } & $W$ & Rank & $W$ & Rank & $W$ & Rank \\
\hline Internet users & 0.240 & 1 & 0.243 & 1 & 0.252 & 1 \\
\hline $\begin{array}{l}\text { Internet } \\
\text { bandwidth }\end{array}$ & 0.165 & 4 & 0.189 & 4 & 0.186 & 4 \\
\hline $\begin{array}{l}\text { Electric power } \\
\text { consumption }\end{array}$ & 0.209 & 3 & 0.216 & 3 & 0.224 & 3 \\
\hline $\begin{array}{l}\text { Air passengers } \\
\text { Telephone }\end{array}$ & 0.148 & 5 & 0.120 & 5 & 0.111 & 5 \\
\hline $\begin{array}{l}\text { Eigen value } \\
\text { (component 1) }\end{array}$ & 2.848 & 2 & 0.231 & 2 & 0.227 & 2 \\
\hline $\begin{array}{l}\text { Proportion } \\
\text { explained (\%) }\end{array}$ & 56.960 & & 63.730 & & 62.480 & \\
\hline
\end{tabular}




\section{Appendix 2. Data Sources}

\begin{tabular}{|c|c|}
\hline Variables & Sources \\
\hline Services export & $\begin{array}{l}\text { Statistics on International Trade in } \\
\text { Services, OECD }\end{array}$ \\
\hline GDP and GDP per capita of exporter & \multirow{2}{*}{$\begin{array}{l}\text { World Development Indicators } \\
\text { 2010, World Bank }\end{array}$} \\
\hline GDP and GDP per capita of importer & \\
\hline $\begin{array}{l}\text { Services trade facilitation indicators comprising (i) internet } \\
\text { users (per } 100 \text { people), (ii) international internet bandwidth } \\
\text { (bits per person), (iii) electric power consumption (kWh per } \\
\text { capita), (iv) air transport passengers carried (per } 100 \text { people), } \\
\text { (v) Fixed line and mobile phone subscribers (per } 100 \text { people), } \\
\text { and (vi) ICT expenditure }\end{array}$ & $\begin{array}{l}\text { World Development Indicators } \\
\text { 2010, World Bank }\end{array}$ \\
\hline Regulatory quality of exporter and importer & $\begin{array}{l}\text { Worldwide Governance Indicators, } \\
\text { World Bank Institute }\end{array}$ \\
\hline Global competitiveness index of exporter and importer & $\begin{array}{l}\text { World Development Indicators } \\
\text { 2010, World Bank }\end{array}$ \\
\hline Exchange rate of exporter & $\begin{array}{l}\text { World Development Indicators } \\
\text { 2010, World Bank }\end{array}$ \\
\hline Distance between exporter and importer & CEPII \\
\hline Language dummy & CEPII \\
\hline Landlocked dummy & \multirow{3}{*}{ Authors own calculation } \\
\hline RTA(FTA) dummy & \\
\hline Adjacency dummy & \\
\hline Control of corruption & Transparency International \\
\hline
\end{tabular}




\section{Appendix 3. List of India's Partner Countries}

\begin{tabular}{|c|c|}
\hline No. & Country \\
\hline 1 & Australia \\
\hline 2 & Austria \\
\hline 3 & Bangladesh \\
\hline 4 & Belgium \\
\hline 5 & Brazil \\
\hline 6 & Canada \\
\hline 7 & China \\
\hline 8 & Czech \\
\hline 9 & Denmark \\
\hline 10 & Finland \\
\hline 11 & France \\
\hline 12 & Germany \\
\hline 13 & Greece \\
\hline 14 & HK \\
\hline 15 & Hungary \\
\hline 16 & Ireland \\
\hline 17 & Italy \\
\hline 18 & Japan \\
\hline 19 & Korea \\
\hline 20 & Luxembourg \\
\hline 21 & Netherlands \\
\hline 22 & Norway \\
\hline 23 & Poland \\
\hline 24 & Portugal \\
\hline 25 & Russia \\
\hline 26 & Slovak \\
\hline 27 & Singapore \\
\hline 28 & South Africa \\
\hline 29 & Sri Lanka \\
\hline 30 & Sweden \\
\hline 31 & UK \\
\hline 32 & USA \\
\hline
\end{tabular}




\section{Appendix 4. Basic Facts of Data}

\begin{tabular}{|c|c|c|c|c|c|c|}
\hline Variable & Abbreviation & Obs. & Mean & Std. Dev. & Min & Max \\
\hline Exports & ex & 224 & 18.207 & 2.615 & 0.000 & 22.760 \\
\hline GDP of reporter & gdp_r & 224 & 27.149 & 0.251 & 26.850 & 27.540 \\
\hline GDP of partner & gdp_p & 224 & 26.492 & 1.475 & 23.480 & 30.210 \\
\hline GDP per capita of reporter & gdppc_r & 224 & 6.344 & 0.224 & 6.110 & 6.710 \\
\hline GDP per capita of partner & gdppc_p & 224 & 9.525 & 1.239 & 5.860 & 11.170 \\
\hline Internet users of reporter & intusr_r & 224 & 0.707 & 0.933 & -0.610 & 2.060 \\
\hline Internet users of partner & intusr $\_p$ & 224 & 3.128 & 1.293 & -2.640 & 4.490 \\
\hline $\begin{array}{l}\text { International internet bandwidth } \\
\text { of reporter }\end{array}$ & iibw_r & 224 & 1.474 & 1.252 & -0.190 & 3.190 \\
\hline $\begin{array}{l}\text { International internet bandwidth } \\
\text { of partner }\end{array}$ & iibw $\_p$ & 224 & 6.608 & 2.654 & -2.170 & 10.460 \\
\hline $\begin{array}{l}\text { Per capita consumption of } \\
\text { electricity of reporter }\end{array}$ & pce_r & 224 & 6.089 & 0.080 & 6.000 & 6.220 \\
\hline $\begin{array}{l}\text { Per capita consumption of } \\
\text { electricity of partner }\end{array}$ & pce_p & 224 & 8.605 & 1.054 & 4.560 & 10.150 \\
\hline $\begin{array}{l}\text { Air transport passengers } \\
\text { carried of reporter }\end{array}$ & air_r & 224 & 16.917 & 0.297 & 16.640 & 17.510 \\
\hline $\begin{array}{l}\text { Air transport passengers } \\
\text { carried of partner }\end{array}$ & air_p & 224 & 16.385 & 1.642 & 10.670 & 20.400 \\
\hline $\begin{array}{l}\text { Fixed line and mobile phone } \\
\text { subscribers of reporter }\end{array}$ & tel_r & 224 & 2.006 & 0.555 & 1.270 & 2.930 \\
\hline $\begin{array}{l}\text { Fixed line and mobile phone } \\
\text { subscribers of partner }\end{array}$ & tel_p & 224 & 4.533 & 0.913 & -0.590 & 5.350 \\
\hline ICT expenditure of reporter & ictexp_r & 224 & 3.269 & 0.427 & 2.790 & 3.910 \\
\hline ICT expenditure of partner & ictexp_p & 224 & 6.695 & 1.391 & 1.920 & 8.250 \\
\hline Regulatory quality of reporter & reg_r & 224 & -0.231 & 0.086 & -0.360 & -0.110 \\
\hline Regulatory quality of partner & reg_p & 224 & 0.641 & 0.634 & -3.200 & 1.120 \\
\hline Global competitiveness of reporter & gci_r & 224 & 1.416 & 0.031 & 1.400 & 1.490 \\
\hline Global competitiveness of partner & gci $\_$p & 224 & 1.567 & 0.153 & 1.040 & 1.780 \\
\hline Control of corruption of reporter & $\mathrm{cc}_{-} \mathrm{r}$ & 224 & 1.046 & 0.063 & 0.990 & 1.190 \\
\hline Control of corruption of partner & cc $\_p$ & 224 & 1.766 & 0.503 & -0.920 & 2.300 \\
\hline Exchange rate of reporter & exr_r & 224 & 3.826 & 0.030 & 3.790 & 3.880 \\
\hline Exchange rate of partner & exr_p & 224 & 1.585 & 1.970 & -0.690 & 7.160 \\
\hline Distance between reporter and partner & dis & 224 & 8.660 & 0.428 & 7.260 & 9.560 \\
\hline
\end{tabular}

(Note) taken in log scale 